\title{
A Unified Model of Political Risk
}

June 26, 2015

Benjamin A.T. Graham School of International Relations, University of Southern California

Noel P. Johnston Blavatnik School of Government, Oxford University

Allison F. Kingsley School of Business Administration, University of Vermont

Note: Author order is alphabetical by convention. All authors contributed to this paper equally.

\begin{abstract}
Purpose: Political risk is a complex phenomenon. This complexity has incentivized scholars to take a piecemeal approach to understanding it. Nearly all scholarship has targeted a single type of political risk (expropriation) and, within this risk, a single type of firm (MNCs) and a single type of strategic mechanism through which that risk may be mitigated (entry mode). Yet "political risk" is actually a collection of multiple distinct risks that affect the full spectrum of foreign firms, and these firms vary widely in their capabilities for resisting and evading these risks. Design: We offer a unified theoretical model that can simultaneously analyze: the three main types of political risk (war, expropriation, and transfer restrictions); the universe of private foreign investors (direct investors, portfolio equity investors, portfolio debt investors, and commercial banks); heterogeneity in government constraints; and the three most relevant strategic capabilities (information, exit, and resistance). Findings: We leverage the variance among foreign investors to identify effective firm strategies to manage political risk. By employing a simultaneous and unified model of political risk, we also find counterintuitive insights on the way governments trade off between risks and how investors use other investors as risk shields.
\end{abstract}

Keywords: political risk, foreign investment, strategy, emerging markets, game theory 


\section{Introduction}

Investors in Argentina are a bit like boat owners. The day they buy and the day they sell are their two best days; in between there's often heartbreak. This past century the Argentine government has serially defaulted on its sovereign debt, expropriated countless foreign companies, repeatedly jacked up its currency controls and transfer restrictions, and even invaded an island. Yet numerous multinational companies, an array of institutional investors, and even brave individuals have invested in Argentina. The ones who made money have done so almost exclusively through strategic execution. Some foreign investors partner with the government or influential local companies, or gain privileged information from Argentine elites; many choose liquid or "hot" investments, while others mount fierce resistance to any adverse government action. How can we understand which investors use what strategies in the face of what type of political risk? When can being smart, fast, or strong manage the risks of war, expropriation and transfer restrictions?

Existing research offers little satisfying theory to simultaneously explain these observations about investment in a politically risk country like Argentina. Admittedly political risk is a complex phenomenon. This complexity has incentivized scholars to take a piecemeal approach to understanding it. Nearly all scholarship has targeted a single type of political risk and, within this risk, a single type of investor and a single type of strategic mechanism through which that risk may be mitigated. In this paper we aim to develop a unified theoretical model of political risk that better explains these heterogeneous observations about risks, investors, and strategic capabilities.

While scholarship has focused primarily on expropriation risk, in the case of Argentina and others, we observe that investors are exposed to heavy losses from other political risks. "Political risk" is in fact a collection of multiple distinct risks, only one of which is expropriation. We begin with a broad definition of political risk as the risk that the host government fails to uphold the terms of an implicit contract between the host government and an investor. This gives rise to a typology of political risk that organizes the distinct ways in which this implicit contract may be violated. We identify war risk, expropriation risk, and 
transfer risk as the three main types of political risk.

Within this typology, the ravages of war constitute a violation of the host government's commitment to protect the investor's assets and personnel from violence. Expropriation risk encompasses more direct actions taken by the host government to seize the assets of foreign investors, including the outright nationalization of assets. We also focus on transfer risk as a particularly common and costly form of creeping expropriation. Transfer risk is the risk of restrictions on investors' ability to convert and transfer capital out of the host country. As the world has become gradually more peaceful and as outright nationalization has become steadily less common, transfer risk has emerged as the most pervasive and costly political risk faced by foreign investors (Graham, Johnston, and Kingsley, 2015). For instance, the Argentine government confiscates through exchange controls in only a matter of weeks the equivalent of one massive, headline-grabbing expropriation like YPF Repsol. ${ }^{1}$

While foreign direct investment (FDI) by multinational companies (MNCs) dominates research on international investment in Argentina and across emerging markets, other flows of private foreign capital are rising in prevalence. We disaggregate foreign investment into four constituent segments, each of which is associated with a particular type of firm. ${ }^{2}$ Direct investors, usually MNCs, occupy controlling (>10\%) ownership positions in local companies. Portfolio equity and portfolio debt investors, usually large institutional investors such as pension funds, mutual funds, and insurance companies, own shares $(<10 \%)$ or corporate bonds of local companies purchased on local public exchanges. Bank lenders, i.e. foreign commercial banks, issue loans to diverse enterprises in the host country.

\footnotetext{
${ }^{1}$ Author's calculation based on daily volumes of currency exchanged at the official rate and the spread between the official rate and the "blue market" unofficial rate.

${ }^{2}$ This typology has the added benefit of aligning with disaggregation by the International Institute of Finance (IIF). This facilitates the use of IIF data in tests of our theory.
} 


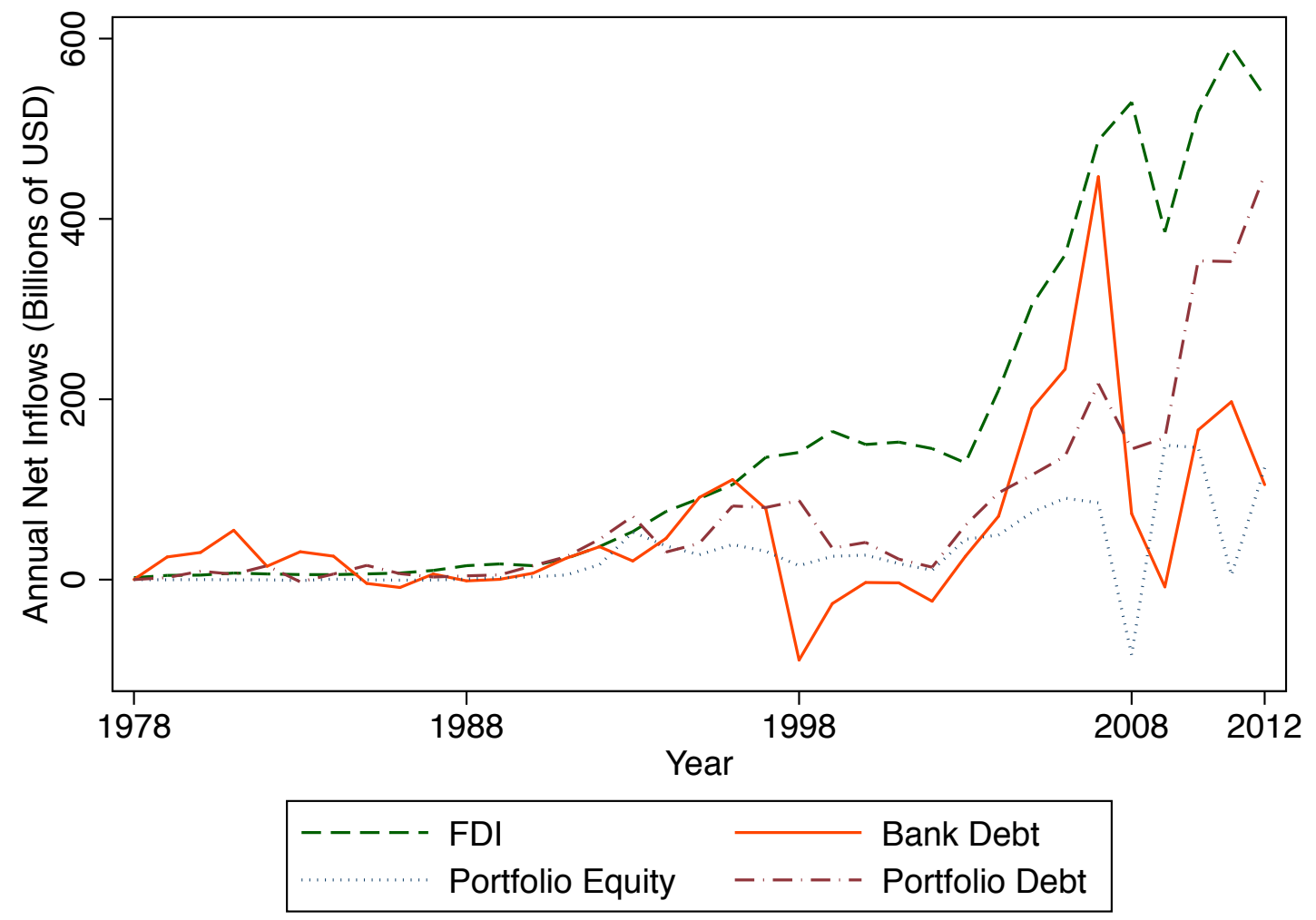

Figure 1: Investment Volume into Emerging Markets

As Figure 1 shows, FDI remains the single largest source of foreign capital into emerging markets. However, in most years FDI accounts for less than half of foreign investment. ${ }^{3}$ This suggests that the traditional focus on MNCs limits academic understanding of foreign investors and may fail to explain other substantively important global capital firms. Investigating variation across the universe of private capital investors can thus provide insight into the calculus of different types of firms and investors beyond simply the MNC. ${ }^{4}$

In Argentina and beyond, we observe significant heterogeneity in investor strategies to mitigate and manage political risk. Research identifies institutional characteristics of the host government, such as domestic political constraints, that affect political risk (e.g. Jensen

\footnotetext{
${ }^{3}$ Figure 1 is based on data from the Institute for International Finance (IIF) and covers investment into the 30 largest emerging markets.

${ }^{4}$ This paper employs stylized facts about the universe of private foreign investor types to motivate the formal model's hypotheses and predictions about firm-level strategy, as discussed in subsequent sections. We use "investors" and "firms" as interchangeable terms, recognizing that some investors (e.g. portfolio debt and equity investors) may represent multiple types of firms.
} 
2003, 2006; Li and Resnick 2003; Henisz 2000; Delios and Henisz 2003; Weingast 1995) but political institutions are largely exogenous to investors and fail to fully explain persistent economic institutions (Acemoglu and Robinson 2006; Alston, Harris, and Mueller 2008) or many types of losses investors face, notably transfer risk (Graham, Johnston, and Kingsley 2015). Another rich body of work exists on the roles of entry mode (e.g. Anderson and Gatignon 1986; Brouthers 2002; Hennart 2009) and manager experience or learning (e.g. Delios and Beamish 2001; Maitland and Sammartino 2014) as means to mitigate political risk. The strategy literature has further found that firms develop nonmarket strategies to manage the political environment (e.g. Baron 1995; Hillmann and Hitt 1999; Bonardi, Hillman, and Keim 2005; Kingsley, Vanden Bergh, and Bonardi, 2012; Kingsley and Vanden Bergh, 2015), even as it changes over time (Emmons 2000; Henisz and Zelner 2005) We build on these existing insights, developing a structured and comprehensive account of the the wide array of relevant investor capabilities. Here, we identify and analyze three main categories of investor capability: level of information, ease of exit, and ability to resist. We leverage this variance among our universe of investors to identify effective firm strategies to manage political risk.

To integrate risks, investors, and capabilities, we construct a unified model of political risk that simultaneously analyzes: the three main types of political risk (war, expropriation, and transfer restrictions); the universe of private foreign investors (direct investors, portfolio equity investors, portfolio debt investors, and commercial banks); and the three most relevant investor capabilities (information, exit, and resistance). We employ this model to evaluate equilibria in which foreign investors will enter a host country under threat of war, transfer restriction and expropriation. The game features two players: a host government and a foreign investor. We evaluate the conditions under which: investment occurs; the government expropriates; the government imposes transfer restrictions; and the foreign investor chooses to expedite repatriation of assets. We model the behavior of the "average" foreign investor in a given market. However, we specify the model in such a way that we can assign varying capabilities to that investor, which we match theoretically to different 
classes of investor, such as direct investors or foreign banks. Similarly, we can vary the incentives of the host government, allowing us to explore the implications of variation in regime type or the existing portfolio of investors. Lastly, we can also vary the risk of war. Thus, by assessing comparative statics of the model, we can assess the changing implications for both government and investor behavior as we vary risk-type, investor-type, and players' capabilities endowment.

The paper proceeds, first, by developing a typology of political risk and introducing the formal model. We then present theory articulating how investor capabilities vary across classes of investment and we map these capabilities to specific parameter values in the model. Next we exploit comparative statics from the model to analyze which capabilities mitigate investors' exposure to which political risks paying particular attention to resistance capabilities. This analysis generates both testable hypotheses for an empirical research program and direct implications for the strategy of firms investing overseas. We conclude by discussing the (counterintuitive) insights that a simultaneous and unified model of political risk offer scholars of governments and firms.

\section{Theory: A Unified Model of Political Risk}

\subsection{Disaggregating Political Risk}

Writing in the late 1970s, Stephen Kobrin bemoaned that definitions of the term "political risk" were vague and over broad, with agreement between scholars "limited to an implication of unwanted consequences of political activity (1979: 67)." A consensus definition has continued to elude the scholarly community because political risk is not, in fact, a single risk but rather a diverse collection of related risks. In this project, we develop a typology of political risk that reflects this heterogeneity, and then bring these risks together under a single unified framework.

Establishing and enforcing a stable property rights regime can be difficult within a sovereign state - many governments fail to secure the property rights of their own citizens 
- but securing the property rights of foreign investors is harder still. Within states, the central government functions as the lawgiver, establishing the bounds of the rights that property holders may expect to enjoy. In the international sphere, no such lawgiver exists and the bounds of the property rights to which foreign investors are entitled remain actively contested (e.g. Hadfield and Weingast 2012; 2013). Thus, we do not conceptualize of international property rights as a fixed set of universal rights of property holders; instead we think of each property holder as entering into an implicit contract with the government of the country in which property is held. ${ }^{5}$ The nature of that contract, and hence the nature of investors' property rights, vary across countries, sometimes even across investors within a given country, and often across time, especially as reforms and emergent institutions unfold (Emmons 2000).

The same institutions intended to secure the property rights of foreign investors (i.e. reduce political risk) are also attempts to shape the bounds of those rights. The text of bilateral investment treaties (BITs), the terms of political risk insurance contracts issued by state-backed political risk insurers, and the opinions written by judges at the Hague and the district court of New York can all be understood as various actors staking out their position regarding the set of property rights to which foreign investors should be entitled. This contestation over the terms of investors' de jure rights both affects and is affected by a parallel contestation regarding the types of violations that investors, home-country governments, and host-country publics will attempt to sanction via collective punishment, i.e. the terms of investors' de facto rights (Alston, Harris, and Mueller 2008). Thus, our model of the conditions under which governments violate or respect international property rights is informed by the ongoing process through which those emergent rights are defined (Henisz and Zelner 2005).

We conceive of political risk as the risk that the host government violates the terms of its implicit contract with a foreign investor. In stylized form, this contract commits the host government to refrain from the direct seizure of assets; to honor explicit contracts;

\footnotetext{
${ }^{5}$ This notion of an implicit contract aligns with Frieden (1994) and Henisz and Zelner (2005), among others.
} 
to provide equal protection under the law; to allow the transfer of capital out of the host country at market exchange rates; and to protect assets and personnel from violence. ${ }^{6}$ In return, the foreign investor commits to abide by domestic law. Thus, our typology of political risk incorporates violations of any of these commitments by the host government.

Because the terms of the contract between host government and investor continue to evolve, no typology of political risk is set in stone for all time. Similarly, any given set of host government commitments can be usefully grouped in several different ways. In this project, we adopt a market-based typology in line with current practice in the broader political risk community, which includes investors, insurers, ratings agencies, governments, and the international legal community. ${ }^{7}$ Following these actors, we distinguish between three types of political risk: war risk, expropriation risk, and transfer risk (also known as inconvertibility).

The archetypical manifestation of expropriation risk is the nationalization of property. Nationalization is easily observed and violates well-established investor rights. For reasons we will discuss in more detail later, outright expropriation has become increasingly costly for host governments and has been declining in frequency since the early 1980s (Minor 1994; Henisz and Zelner 2010).

As outright expropriation has declined in prevalence, it has been supplanted by more subtle acts of "creeping expropriation," which include selective taxation, selective regulation, government breach of contract, and transfer restriction (e.g. Weston 1975; Kobrin 1984; Wellhausen 2013). Among these we focus on the risk of transfer restriction because these restrictions are common, costly, and currently front and center in debates over the boundaries of investor property rights (Graham, Johnston, and Kingsley, 2015). The governments of major investment-sending countries like the U.S. have been actively working to forge a consensus recognizing transfer restrictions as a violation of investor property rights, while

\footnotetext{
${ }^{6}$ Pursuing different research questions, Graham (2014) also examines host government commitments to enforce contracts between private parties.

${ }^{7}$ In particular, our typology matches those of the World Bank's Multilateral Investment Guarantee Agency (MIGA); the Overseas Private Investment Corporation (OPIC); the Berne Union; and the Credendo Group (formerly ONDD), the market leader in private political risk insurance.
} 
the governments of investment-receiving countries have been pushing back (e.g. RoseAckerman and Tobin 2009). This contestation was particularly acute surrounding failed attempts by the OECD in the late 1990s to create a Multilateral Agreement on Investment that would have endowed foreign investors with much stronger property rights than those available under the 1994 Agreement on Trade Related Investment Measures (Deere 2009). Investment sending countries have been more successfully in enshrining expansive property rights in BITs than in multilateral agreements; however, in some ways this only underscores the lack of an international consensus on investor rights vis-a-vis transfer restrictions and other types of creeping expropriation.

Both expropriation and transfer restrictions are means through which host governments extract wealth from foreign investors, causing costly losses to foreign investors and potentially to the government itself. In contrast, war is typically costly to both investors and host governments. War frequently violates the host governments' commitment to protect assets and personnel (e.g. Ghobarah, Huth, and Russett 2003; Oetzel and Getz 2012) and remains a salient political risk. From 1972 to 2002, losses from war generated only a small number of claims with Berne Union members (12\% of the total), but the claims were large, accounting for half of all claimed losses by value.

\subsection{Modeling Each Risk}

A formal model forces precision regarding the characteristics ascribed to each type of political risk. To generate our modeling assumptions, we draw on the existing scholarly literature as well as descriptive statistics from the universe of political risk insurance claims that have been filed with MIGA, OPIC, and the Berne Union.

War is not the most preferred outcome of any of the parties involved and both its onset and its termination are difficult to predict (e.g. Fearon 1995; Hegre 2004). Thus, we model the (non)occurrence of war as the result of a move by Nature, rather than as the result of a deliberate action taken by the host government. This is consistent with the treatment of war in commercial contracts as an event equivalent to acts of God. If war occurs, it imposes 
costs on the foreign investor both by destroying assets and by affecting the rate of return on assets that remain intact.

Expropriation is a deliberate strategy for seizing wealth from foreign investors and typically targets only one or a few investors at a time. When the assets to be seized are liquid, host governments typically take great care to keep expropriations secret before they are enacted in order to prevent investors from moving assets outside the host country before they can be seized. ${ }^{8}$ Thus, we model the average investor as unable to predict expropriation events before they occur. ${ }^{9}$

Transfer restrictions are more limited than expropriation in that they only target a subset of investor assets - those assets that the investor wishes to move out of the host country. However, transfer restrictions are typically economy-wide, hitting all foreign investors in the host country simultaneously. Implementing such economy-wide restrictions is complex and requires coordination between multiple branches of government. For example, effective foreign exchange restrictions require mobilizing both the central bank and private banks (to restrict the electronic transfer of funds); customs enforcement (to prevent the physical movement of currency across the border); and domestic law enforcement (to shut down black-market currency exchanges). While governments aspire to implement such restrictions in a manner unforeseen by foreign investors, doing so is inherently difficult. Thus, investors typically enjoy a small window during which they know that restrictions are imminent, but in which repatriation of assets is still possible. This is reflected in our model by the assumption that, prior to transfer restrictions taking effect, the average investor has the opportunity to expedite repatriation of their assets - i.e. to slip some assets out of the country before the restrictions take effect.

The characterizations of war, expropriation, and transfer risk introduced in this section

\footnotetext{
${ }^{8}$ When investments are not liquid, governments can take time consuming steps such as passing laws authorizing and justifying the expropriation - effectively taking steps to make the expropriation more lawful and reduce the eventual costs of settlement.

${ }^{9}$ We acknowledge that some extremely well connected investors exist that can foresee these events (and that some expropriations move slowly). In the model that follows, if an investor could foresee expropriation, then she would face an option of costly expedited repatriation similar to that we model for transfer risk. The more liquid the underlying assets, the lower the costs of expedited repatriation.
} 
inform the theoretical model that follows.

\section{Theoretical Model: An Extensive-Form Game with War, Transfer Restrictions, and Expropriation}

To begin a discussion of the environment of political risk, we find conditions under which it is optimal for a foreign investor to invest in a foreign country, despite the risks of: violence or war breaking out; increased transfer costs for the repatriation of capital; and outright expropriation of assets.

We characterize an equilibrium where this behavior occurs, and then analyze how the equilibrium behavior changes with respect to different types of investors.

We model the relationship between a host government and a foreign investor as a fivemove game. Define this investor as the average investor over a range of investor types, investment sizes, and sectors.

\section{Structure of the Game}

In each round of play, a foreign investor $(F)$ faces three distinct risks. First, there is a risk violence breaking out in the host country. If violence does not break out, there remains the risk that the government $(G)$ will choose to extract rents from the foreign investor by increasing the rents gained from $F$ repatriating assets, or by expropriating assets. ${ }^{10}$ At the beginning of the game, the foreign investor can either invest $(I)$ or not invest $(\neg I)$. If $F$ invests, Nature $(N)$ moves and determines two things: first, if the host country breaks out into war with probability $r$, and second; the cost $\left(C_{T}\right)$ associated with transfer rents.

If $N$ selects war, the game ends. If not, the game proceeds. $G$ directly observes the value of $C_{T}$ that has been assigned, and based on that value, the government can either

\footnotetext{
${ }^{10}$ We assume that the host government prefers more revenue to less, but cannot control these mechanisms equally. War, for example, is seldom induced for the sake of seizing rents from a foreign investor, but it can nevertheless lead to damages for the investor. In this paper, we make no assumption about how governments intend to use this revenue; however we note that autocrats may value the personal wealth created by rents, whereas democratic governments may value the political benefits of redistributing the rents from foreign parties to domestic constituents.
} 
uphold the investment contract by maintaining the agreed-upon transfer rents, $t_{0}$, or breach the contract by selecting some $t^{\prime}=t_{0}+\tau$, where $\tau>0 .{ }^{11}$ The foreign investor is imperfectly informed about the level of $C_{T}$. She perceives, with probability $p$, that the value of $C_{T}$ has been set such that the host government will breach its contract by selecting $t^{\prime} .{ }^{12}$ Based on this perception, $F$ selects what level $(\epsilon)$ to expedite repatriation before the new policy is announced. $G$ then decides whether or not to expropriate assets. ${ }^{13}$ Figure 2 displays this five-move game.

\footnotetext{
${ }^{11} G$ prefers to breach when the following condition is satisfied: $C_{T} \leq R \alpha(1-\mu)+\mu V \gamma\left(t_{0}+\tau\right)+C_{E}-\omega$.

${ }^{12}$ Note that $t^{\prime}$ or $t_{0}$ is a strategic choice made by $G$, and not directly by $N$. $N$ simply selects $C_{T}$, which is, albeit, critical to informing $G^{\prime}$ s choice between $t^{\prime}$ and $t_{0}$.

${ }^{13}$ If $G$ expropriates, this model assumes that $F^{\prime}$ s intention to expedite repatriation is unrealized - that the assets will be seized in either case. This simulates the difference between endogenous risk, which can be mitigated by informational advantages and structural capabilities, and exogenous risk, which cannot. An alternative version could allow $F$ to salvage some of their assets even in the case of outright expropriation.
} 


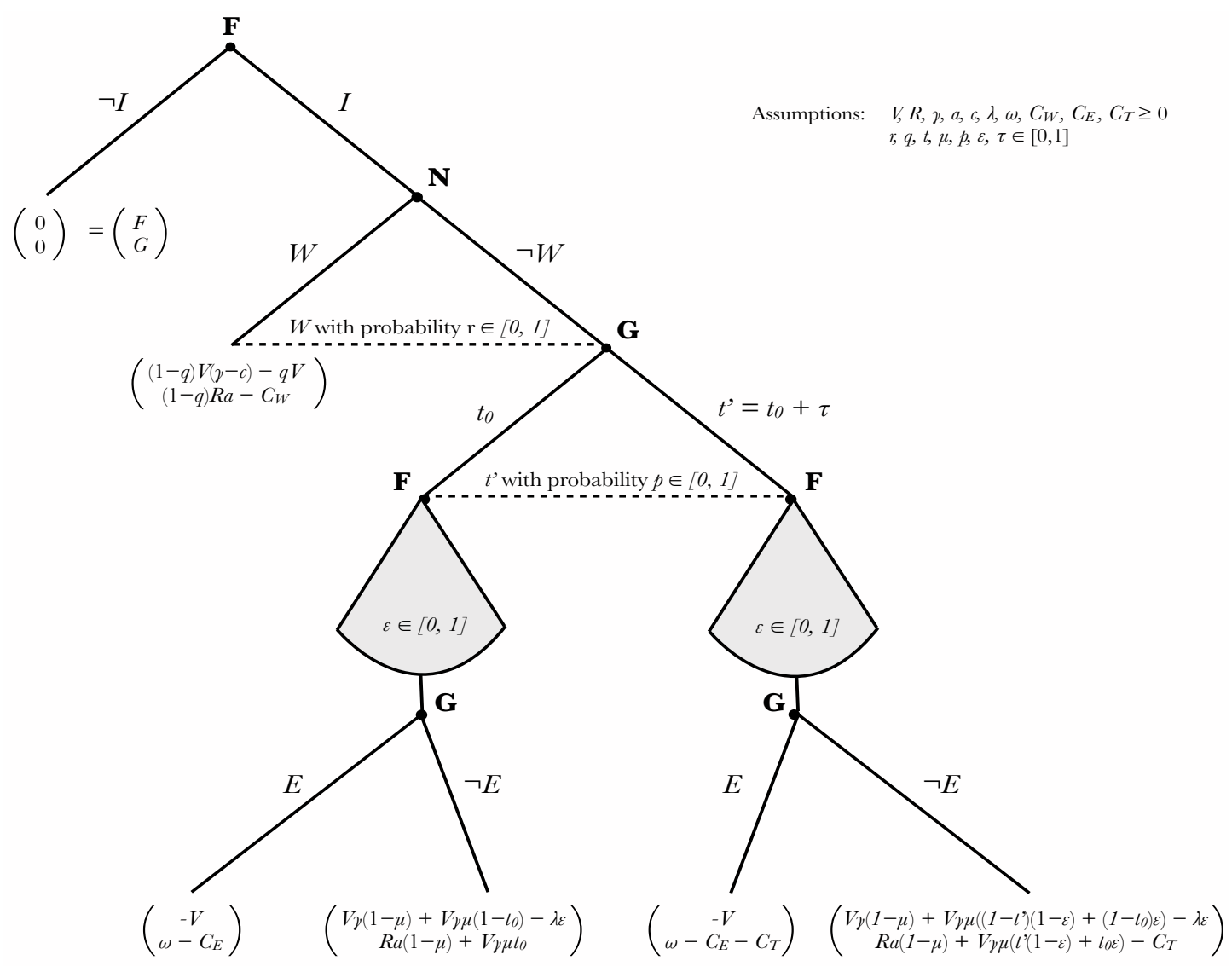

Figure 2: A two-player extensive-form game in which a foreign investor $(F)$ chooses whether or not to invest; Nature $(N)$ chooses war or no war (with probability $r$ ); if a war does not occur, a host government $(G)$ chooses at what level $(t)$ to set transfer restrictions on that investment; $F$ chooses, before the new policy is announced (but seeing a $p$-probability of transfer breach), at what level to expedite repatriation $(\epsilon)$; and $G$ decides whether to expropriate or not. Here, if Nature chooses 'War', the round of play ends. F loses part of her investment and any residual may receive a lower rate of return.

\section{Investor Incentives}

As shown in Figure 2, if the foreign investor plays $\neg I$, both players receive zero. Suppose $F$ chooses to invest. Denote $V$ as the amount they will invest and $\gamma$ as the expected rate of return if $F$ plays $I .{ }^{14}$ If $N$ selects war, the game ends, with $F$ losing a $q \in(0,1)$ amount of her original investment and receiving an adjusted rate of return, $\gamma-c$, on the remaining $(1-q)$ amount: $(1-q) V(\gamma-c)-q V$. If conflict does not break out in the host country,

\footnotetext{
${ }^{14} \gamma$ is a function of various investment indicators.
} 
the game proceeds. Denote $\mu \cdot V \gamma$ as the portion $F$ intends to repatriate $(\mu \in[0,1])$, amid transfer restrictions $t_{0}$, and $\epsilon$ as the amount of repatriation $F$ expedites, upon anticipating a transfer breach. Define $\lambda \cdot \epsilon$ as the cost of expedited repatriation $(\lambda \geq 0) .{ }^{15}$ If the investor plays $I$, she receives a maximum of $V \gamma(1-\mu)+\mu V \gamma\left(1-t_{0}\right)$. This occurs if $G$ upholds the investment contract and $F$ plays $\epsilon=0$; the payoff is a weighted sum of what she earns on her non-repatriated assets $(1-\mu)$ and her repatriated portion $\left(\mu\right.$, subject to $\left.t_{0}\right)$. The investor receives a minimum of $-V$, when $G$ plays $E$. Thus, while the investor prefers to invest with minimal transfer restrictions and without the threat of expropriation, she may or may not prefer intermediate transfer restrictions (or a chance of expropriation) to the reservation payoff of zero, depending on the probability of transfer breach $(p)$, the probability of war $(r)$, and how lucrative the investment opportunity is $(\gamma)$.

\section{Government Incentives}

The host government $(G)$ works in this game to balance tradeoffs between its desire for revenue in the current period with competing demands for domestic political support, future revenue, and good diplomatic relations with the governments of investment-sending countries. These complex preferences are fed into the model in a relatively simple way, as factors determining $\omega$, which is the value to $G$ of $F^{\prime}$ s assets if they are owned by the government (i.e. expropriated outright), and $C_{E}$ and $C_{T}$, which are the costs of backlash $G$ receives after expropriation or a unilateral increase in transfer restrictions, respectively.

$C_{E}$ and $C_{T}$ capture a range of negative impacts accruing to the host government as a result of its expropriation/transfer restriction actions. Most important among these are: 1) Monetary settlements levied if the host government is found in violation of its treaty commitments; 2) Lost future investment; 3) Diplomatic costs imposed by the governments of investment home countries; and 4) Domestic political costs imposed by the domestic public (or a subset thereof).

The severity of settlement costs varies depending on the precise terms of the treaties to

\footnotetext{
${ }^{15} \mathrm{~A}$ future model could analyze a more general cost function, $f(\epsilon)$, such that $f(0)=0$ and $f^{\prime}(\epsilon) \geq 0$.
} 
which the host government is party to, i.e. it depends on the strength of investors' de jure property rights. The severity of lost future investment, diplomatic costs, and domestic political costs are determined by the respective abilities of investors, home-country governments, and the domestic public to engage in collective punishment, i.e. the strength of investors' de facto property rights. Collective punishment is most effective when the community of potential punishers can coordinate on what does and does not constitute a violation. ${ }^{16}$ Enshrining a particular right in a treaty or in domestic law enhances collective punishment by easing this coordination, but collective enforcement is possible even for rights that do not exist in de jure form.

In related work, we develop theory regarding why the blowback costs for expropriation $\left(C_{E}\right)$ increase as domestic political constraints increase, while the blowback costs of transfer restriction $\left(C_{T}\right)$ are largely unaffected by those same constraints. This distinction emerges primarily because investors' de facto rights are stronger with regard to expropriation, leading to more effective censure of the government by the domestic public (Graham, Johnston, and Kingsley, 2015). Both outright and (non-transfer) creeping expropriation violate well-established and broadly accepted rights of investors, and both are costly to domestic interests. In contrast, transfer restrictions impose losses almost exclusively on foreigners, ${ }^{17}$ and the right to be free from such restrictions is not universally acknowledged as a right that foreign investors possess. Thus, coordination among potential punishers, particularly members of the domestic public, is hindered by a lack of consensus regarding what constitutes a violation.

There also exists a political component to $\omega$, the government's valuation of assets when owned outright. ${ }^{18}$ We refer to this political component of the valuation as the "political valence" of the assets. For example, state ownership of nationalized firms can provide opportunities for patronage via employment and contracts with the now-state-owned enterprise. Similarly, populist governments may enjoy increased support if they can successfully claim

\footnotetext{
${ }^{16}$ e.g. Hadfield and Weingast 2012.

${ }^{17}$ We acknowledge that some domestic actors, including importers, are also negatively affected, but it is foreign investors who are most likely to bear high costs.

${ }^{18}$ Thus, $V$ and $\omega$ may not be equal: $G$ may value assets differently than $F$.
} 
acts of expropriation as acts of nationalism or independence. Conversely, some fixed assets may be entirely unappealing to the government, leading to a low value of $\omega$. Note that in the case of revenue seized via transfer restriction, $G$ and $F^{\prime}$ s valuation of the revenue is identical and there is no political component to valuation - this revenue is fungible.

Returning to Figure 2, we see that, like the investor, the host government receives zero if $F$ does not invest. Denote $R$ as the government's share in the investment's value. $R$ is a sum of the tax revenue and other benefits that accrue to the government from the investor's operation, and $\alpha$ is the rate of return on that investment. ${ }^{19}$ If war breaks out, the game ends, and $G$ receives $R \alpha$ on the $(1-q)$ undestroyed portion of the investment, minus a war cost, $C_{W}: R \alpha(1-q)-C_{W} \cdot{ }^{20}$ If war does not break out, the game continues. If $F$ invests and $G$ upholds the original investment contract $\left(t_{0}\right), G$ receives $\mu V \gamma t_{0}$ on the portion that $F$ repatriates and $R \alpha(1-\mu)$ on the portion that $F$ does not: $R \alpha(1-\mu)+\mu V \gamma t_{0}$.

If $G$ breaks the contract, selecting $t^{\prime}$, it receives $R \alpha(1-\mu)+\mu V \gamma t^{\prime}(1-\epsilon)-C_{T}$ with the new transfer restrictions and $\mu V \gamma t_{0} \epsilon$ on the amount that $F$ expedites before the policy shift: $R \alpha(1-\mu)+\mu V \gamma\left(t^{\prime}(1-\epsilon)+t_{0} \epsilon\right)-C_{T}$. Finally, if the host government expropriates, it receives $\omega-C_{E}$, and, if it expropriates after increasing transfer restrictions, it receives $\omega-C_{E}-C_{T}$.

Notice that, without the prospect of backlash to a contract violation, the government always prefers to either seize the maximum amount of transfer rents or to directly expropriate, whichever offers the greater return. This creates tension in the game between playing $t^{\prime}$ or $E$, on one hand, and avoiding the backlash, on the other.

To analyze the strategy of investment amid transfer risk, we define a subgame perfect Nash equilibrium (SPE) in which: the expropriated assets are worth enough for $G$ to expropriate if they do not breach the transfer policy (condition 1); and too little if they do breach it (condition 2); the cost of expediting repatriation $(\lambda)$ is sufficiently high so that $F$ plays

\footnotetext{
${ }^{19}$ We envision $\alpha$ as a composite of tax revenue from the international corporations, profits from joint ventures, and income tax revenue from the public (we allow for the possibility that foreign investment increases the domestic productivity of workers, raising incomes, thus generating more income tax revenue for a given tax rate).

${ }^{20}$ For an elaboration on the $C_{W}$ cost parameter, see footnote 9.
} 
$\epsilon=0$ (condition 3); the cost of increasing transfer restrictions $\left(C_{T}\right)$ is sufficiently low for $G$ to consider playing $\mathrm{t}^{\prime}$ (condition 4); and $F$ prefers to invest, despite the $r$-probability of war and the $p$-probability of transfer breach (condition 5). Put differently, we define an SPE where $F$ strategy is to invest, despite the risk of war, and the possibility of expropriation and transfer risk, where war winds up not occurring, and where G's strategy is to play $\left\{t^{\prime}, \neg E\right\}$ when $C_{T}$ is sufficiently low, and $\left\{t_{0}, E\right\}$ otherwise. Formally:

Definition 1 A political risk equilibrium is an equilibrium in which $F$ plays $\{I, \epsilon=0\}$, and $G$ plays $\left\{t^{\prime}, \neg E\right\}$ when $C_{T} \leq R \alpha(1-\mu)+\mu V \gamma\left(t_{0}+\tau\right)+C_{E}-\omega$, and $\left\{t_{0}, E\right\}$ otherwise.

Proposition 1 There is a political risk equilibrium when the following conditions hold:

1. $\omega \geq R \alpha(1-\mu)+\mu V \gamma t_{0}+C_{E}$

2. $\omega \leq R \alpha(1-\mu)+\mu V \gamma t^{\prime}+C_{E}$

3. $\lambda \geq \mu V \gamma \tau$

4. $C_{T} \leq \mu V \gamma \tau$

5. $r \leq \frac{1-p-p \gamma\left(1-\mu t^{\prime}\right)}{1-p-p \gamma\left(1-\mu t^{\prime}\right)+(1-q)(\gamma-c)-q}$.

See Appendix for proof. Figure 3 displays an equilibrium path of Proposition 1. Notice how each of the risks are present for the investor: while war does not arise, G selects between $\left\{t_{0}, E\right\}$ (expropriation outcome) and $\left\{t^{\prime}, \neg E\right\}$ (transfer breach outcome), ultimately choosing the latter. 


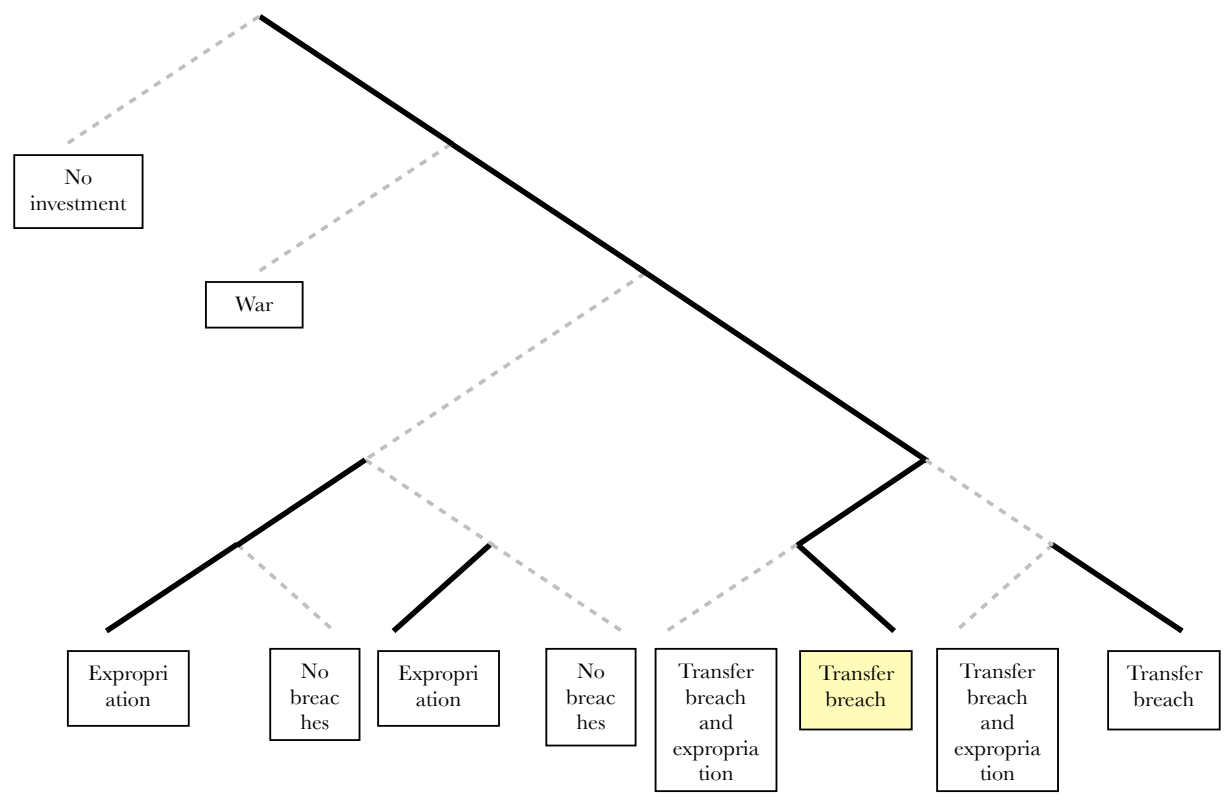

Figure 3: An illustration of an equilibrium path in Proposition 1. Here, war does not occur and the government $(G)$ chooses to increase transfer restrictions but not to expropriate.

At this point, we have demonstrated a logic for how expropriation, war, and transfer risks can accompany investment.

\section{Dynamic Intuitions from the Static Model}

Using this unified framework, we can ask questions that would otherwise be difficult to assess comprehensively. In particular, how do investors view a country's risk profile when there are multiple, distinct risks, and other types of investors entering? Our logic suggests that, by influencing the incentives of the government, the distribution of investor types currently in place can create a risk-shield for some prospective investor types, while increasing the risks faced by other types.

The distribution of capital flows in an economy affects the host government's behavior in important ways. For example, countries that rely primarily on bank debt (versus portfolio flows or direct investment) for foreign investment may face a different set of incentives when it comes to expropriation or imposing new transfer restrictions. ${ }^{21}$ But how? For

\footnotetext{
${ }^{21}$ In this example, we omit war because we assume that, in general, a government does not choose war in
} 
clarity, we focus on one simple distinction - the level of an investor's repatriation - and use it to demonstrate how a government's investment portfolio can influence its risk portfolio (i.e. its willingness to expropriate and impose transfer restrictions).

Let us first assume that investors may vary in their level of repatriation. Portfolio debt and equity investors, for example, repatriate a large share of their profits. While bank lenders also repatriate a material share of profits, some funds may also be used to expand the bank's lending portfolio, build domestic branches, etc. Across types, however, direct investors, as a class, repatriate the least from and reinvest the most in the domestic economy; profits from the initial investment are often plowed back in to expand and grow the affiliate over time, leading to long delays between the initial investment and the eventual repatriation of profits. Thus, let us assume that the amount repatriated $(\mu)$ varies across investment types (i.e. portfolio $(p)$, bank $(b)$, and direct $(d)$ investors) in the following way: $\mu_{p}>\mu_{b}>\mu_{d}$

But how does this matter? Suppose that bank debt is currently the only type of foreign investment in a host country. How might this affect a direct investor's decision to invest? Let us focus on investors' intended levels of repatriation; $\mu_{b}$ and $\mu_{d}$, where $\mu_{b}>\mu_{d}$. Notice that, from proposition 1 above, $\mu$ is one of only two parameters that is common to all four equilibrium conditions (the other being $\gamma$ ), and thus changes in $\mu$ may have non-obvious consequences for the behavior in equilibrium. We begin by looking at G's decision to expropriate or simply increase transfer restrictions.

Define $\mu_{b}=\mu_{d}+b$, where $0<b \leq 1-\mu_{d} \cdot{ }^{22}$ How does increasing $\mu$ affect G's decisions to expropriate or commit a transfer breach? In proposition 1, when $N$ chooses $C_{T} \leq R \alpha(1-\mu)+\mu V \gamma\left(t_{0}+\tau\right)+C_{E}-\omega$ (call this the ' $C_{T}$-condition'), $G$ plays $\left\{t^{\prime}, \neg E\right\}$ over $\left\{t_{0}, E\right\}$. Solving for $\omega$, the $C_{T}$-condition becomes: $\omega \leq R \alpha(1-\mu)+\mu V \gamma\left(t_{0}+\tau\right)+C_{E}-C_{T}$. We see that increasing $\mu\left(\mu_{d} \rightarrow \mu_{b}\right)$ will make this condition easier to satisfy when $\left(1-\mu_{b}\right)+$ $\mu_{b} V \gamma\left(t_{0}+\tau\right)+C_{E}-C_{T}>\left(1-\mu_{d}\right)+\mu_{d} V \gamma\left(t_{0}+\tau\right)+C_{E}-C_{T}$. Substituting $\mu_{b}=\mu_{d}+b$, and solving for $\alpha$, this reduces to: 


$$
\alpha<\frac{V \gamma t^{\prime}}{R}
$$

Notice that conditions (1) and (2), which determine G's expropriation decision (both onand off-path), yield the same condition. Likewise, if the $\alpha$-condition is satisfied, condition (4), which determines the feasibility of a transfer risk breach, is easier to satisfy as $\mu$ increases. Less directly, we can see that increasing $\mu$ makes expediting repatriation more attractive (condition 3) and G more likely to invest (condition 5) (if $q \leq \frac{\gamma-c}{\gamma-c+1}$ ). Overall, if the $\alpha$-condition is satisfied, we see that increasing $\mu$ makes the expropriation conditions more difficult to satisfy, $t^{\prime}$ more feasible, the expatriation condition easier to satisfy, and investment more likely to occur (when $\left.q \leq \frac{\gamma-c}{\gamma-c+1}\right)$ ).

The $C_{T}$-condition is particularly relevant because it determines whether the game ends in transfer breach or expropriation. ${ }^{23}$ Notice the conditionality in the $\alpha$-condition: increasing $\mu$ will make $G$ more likely to behave in such a way that leads to the transfer restrictions outcome $\left(\left\{t^{\prime}, \neg E\right\}\right)$ (over expropriation) in certain circumstances (i.e. when $\alpha<\frac{V \gamma t^{\prime}}{R}$ ), but increasing $\mu$ will have the opposite effect under other circumstances (i.e. when $\alpha>\frac{V \gamma t^{\prime}}{R}$ ). Intuitively, this means that a predominance of foreign bank lending in the host economy affects the government's relative preference for seizing assets via $\left\{t^{\prime}, \neg E\right\}$ vs. $\left\{t_{0}, E\right\}$. And investors are not indifferent to this: some investors stand to lose more to transfer risk than others. Specifically, when transfer restrictions increase, those which repatriate a larger share of their profits, stand to lose more. If, for example, a direct investor were to reinvest all of her capital, she would be unaffected by an increase in transfer risk. On the other hand, that same direct investor remains vulnerable to expropriation risk. Thus, our theory suggests that a predominance of bank debt in a host country changes the relative level of transfer and expropriation risk and, through that change, may further close the door to direct investors (if $\alpha<\frac{V \gamma t^{\prime}}{R}$ ) or open the door (if $\alpha>\frac{V \gamma t^{\prime}}{R}$ ). Thus, by affecting the host country's political risk profile, initial investment conditions influence future investment trends. It also sug-

\footnotetext{
${ }^{23}$ For the remainder of this analysis, we focus on the $\alpha$-condition, which pertains to conditions (1) and (2) and, most importantly, the $C_{T}$-condition. While the other conditions may change with $\mu$, this analysis is more interested on the outcome of the equilibrium (which is determined by the $C_{T}$-condition.)
} 
gests that investors may benefit from being in the minority of investors; of being outside of the predominant group upon which the host government focuses it's political risk policies.

But what does this mean for the prospective direct investor looking in? There are two cases. In one case a high initial endowment of bank debt raises the risk of expropriation relative to transfer breach and thereby deters new entry by direct investors into the host economy. This occurs when $\left(\alpha<\frac{V \gamma t^{\prime}}{R}\right)$. In the second case a high initial endowment of bank debt has the opposite effect, dropping the risk of expropriation relative to transfer breach. This occurs when $\left(\alpha>\frac{V \gamma t^{\prime}}{R}\right)$. These are distinct and opposite effects, meaning that the government can either earn enough on the investment under foreign ownership $(\alpha)$ to simply skim off the top (with transfer restrictions), keeping the production/ownership in the investor's hands, or just expropriate the investment if $\alpha$ is sufficiently low in comparison to its value under national ownership.

Notice that the opposite is implied for portfolio investors. Since portfolio investors repatriate a higher share of their profits, they are more (less) sensitive to transfer breach (expropriation). Thus, the same shift in risks that deters FDI opens the door for portfolio investors, and the same conditions that create a risk shield for direct investors may keep out portfolio investors. The government adapts its strategy to seize assets efficiently from the type of investor that is predominant in the economy. This shifts the political risk profile in the host country and, in turn, effects the relative willingness of different classes of foreign investor to enter.

Table 1 summarizes this logic. 


\begin{tabular}{|l|l|l|}
\hline \multicolumn{3}{|c|}{ Effect of Bank Predominance on Political Risk and Future Investment } \\
\hline$\alpha$-condition & Affect on political risk & Consequences for other investors \\
\hline$\alpha>\frac{V \gamma t^{\prime}}{R}$ & $\frac{\text { transfer restrictions } \uparrow}{\text { expropriation }} \uparrow$ & $\begin{array}{l}\bullet \text { prospective FDI } \uparrow \\
\bullet \text { prospective portfolio investment } \downarrow\end{array}$ \\
\hline$\alpha<\frac{V \gamma t^{\prime}}{R}$ & $\frac{\text { transfer restrictions }}{\text { expropriation }} \downarrow$ & $\begin{array}{l}\bullet \text { prospective FDI } \downarrow \\
\bullet \text { prospective portfolio investment } \uparrow\end{array}$ \\
\hline
\end{tabular}

Table 1: Effect of bank predominance on political risk and future investment.

Notice that we have only looked at the case of bank predominance. If we have three groups of investors, with respect to $\mu$ (portfolio, bank, and direct), there are six other potential initial conditions (of predominance): \{portfolio\}, \{direct\}, \{portfolio \& bank\}, \{portfolio \& direct\}, \{bank \& direct\}, and \{portfolio \& bank \& portfolio\}. We can perform a separate analysis for each of the initial condition possibilities. This can, for example, help us tailor the theory to specific country profiles (which may show predominance with some investors over others), but can also help us understand a country's investment-related path dependence. The simple take away is that, whether for investors inspecting potential investment locations abroad, or host governments interested in attracting a particular type of investment, our theory suggests that initial conditions matter; that a country's existing investment profile may already be leading to certain future investment profiles, while creating barriers for other potentialities.

While simple, this takeaway is non-obvious and emerges only when multiple investor types and multiple risks are considered jointly within a unified model. In the following section, we move beyond variation in how much investors repatriate and examine variation in investor capabilities. 


\section{Capabilities of Investors}

We model the behavior of the "average" foreign investor across a range of investor types. However, investors vary in their capabilities for managing political risk (e.g. Delios and Henisz 2003; Kerner and Lawrence 2014; Wellhausen 2013; Khanna, Palepu, and Bullock 2010). In particular, we focus on variation across investors with regard to: level of information; ease of exit; and ability to resist. Each of these investor characteristics corresponds to a parameter value in our model. Thus, we are able to exploit the comparative statics in our model to assess the exposure of different types of investors to different political risks. First we must establish theoretically which capabilities are likely to be possessed by each type of investor.

An investor's level of information, ease of exit, and ability to resist jointly determine her vulnerability to adverse political events. To avoid or limit losses, an investor must either: a) prevent an adverse political event from occurring; b) shift assets out of the host country before losses are incurred or c) obtain compensation for those losses after they occur (Johnston 2015). In the following sections, we outline how level of information, ease of exit, and ability to resist allow investors to achieve these favorable outcomes.

\subsection{Ability to Resist}

We model war, expropriation, and transfer restriction as ex post irreversible - investors cannot undue these events once they have occurred. This does not mean, however, that investors are passive or powerless in the face of adverse government action. Instead, investors engage in both ex ante and ex post political risk management strategies to reduce the government's incentives to engage in expropriation or transfer restriction. In the context of our model, an investor's ability to resist is directly reflected in the government's costs of expropriation $\left(C_{E}\right)$ and transfer restriction $\left(C_{T}\right)$. The higher the investor's ability to resist, the higher the costs of adverse action against her. As $C_{E}$ and $C_{T}$ increase, it narrows the range of conditions under which the government prefers to expropriate and impose transfer 
restrictions, respectively. ${ }^{24}$

Investors' ability to resist adverse government action is a function both of their de jure power to seek legal redress in response to a host government's violation of its treaty commitments and their de facto power to marshall others actors to collectively punish the violating state. Investors' increase both of these types of power through ex ante and ex post political risk management strategies.

An investor's de jure power is determined by the precise terms of the treaties to which the host government and the investor's home government are party. Thus, investors can and do increase their de jure power by lobbying for specific treaties to be signed (an ex ante strategy), but when they do so, they empower not only themselves but also all other investors from their home country. Ex post strategy for exercising de jure power primarily involves litigation through international arbitration bodies.

The sources of an investor's de facto powers of resistance are perhaps more theoretically interesting. They include: 1) the relationship between the investor and domestic stakeholders, especially joint-venture partners; 2) the regime type in the host country; 3) the ability of the investor to act collectively with other foreign investors to withhold future capital from the host country; and 4) the relationship between the investor's home government and the host government, including military alliances, foreign aid, and the presence of BITs or preferential trade agreements (PTAs).

The role of joint venture partners in reducing political risk vulnerability is well documented in the strategy literature (e.g. Henisz 2000; Delios and Henisz 2003). Domestic partners are, themselves, stakeholders in the domestic government and harming them imposes direct political costs on the host government. Additionally, to the extent that foreign investors hire local employees, purchase inputs from local suppliers, supply difficult-toreplace inputs to local customers, and contribute to the local community via corporate social responsibility (CSR) efforts, they align their interests with the interests of the domestic public more broadly - effectively engaging the domestic public as a shield (Baron 2001;

\footnotetext{
${ }^{24}$ This emerges from the model via backward induction.
} 
Henisz, Dorobantu, and Nartey 2013). If a foreign investor can increase the number of citizens that would be harmed by government action against her, she has engaged in effective ex ante positioning that increases the blowback the government will face for that adverse action (e.g. Markus 2012).

The ability of the domestic public to impose costs on the host government is conditioned strongly by regime type in the host country. Democratic regimes require the support of a majority of their citizens to remain in office; non-democratic regimes may be able to stay in power with the support of a much smaller winning coalition (e.g. Bueno de Mesquita et al. 2003). Thus, democratic regimes are expected to be much more responsive to the concerns of the domestic public. We expect that resistance strategies in which the domestic public plays a pivotal role are most effective in countries where democratic accountability is high. ${ }^{25}$ More targeted local-stakeholder strategies can also be effective in an autocratic context, so long as the local stakeholder in question is part of the political elite. ${ }^{26}$ Thus, regime type conditions the effectiveness of all ex post political risk management strategies, and the decision to invest only under certain types of regime could be considered an ex ante strategy.

Much of the blowback the host government faces following expropriation and transfer restriction comes in the form of lost future investment. The value of this lost future investment is higher when the harmed investors can coordinate widely with other foreign investors. Broad coordination is best achieved by investors in concentrated industries (e.g. Olson 1965) and investors whose co-nationals collectively account for a large share of inward investment to the host country (Welhausen 2014). Thus, the effectiveness of ex post collective punishment can be well predicted by the context in which a firm chooses to invest (an ex ante decision).

Home governments may also intervene directly on behalf of their investors to impose costs on host governments, and mistreatment of investors can have political repercussions

\footnotetext{
${ }^{25}$ Fang and Owen (2011) find that international organizations can serve as a substitute for domestic political constraints, helping autocratic countries credibly commit to open-economy policies.

${ }^{26}$ In the language of Bueno de Mesquita, et al. (2003), part of the "selectorate."
} 
across all facets of the bilateral relationship between home and host government. ${ }^{27}$ Firms that can engage in effective ex post lobbying efforts after they have been harmed can impose high costs on the host government via their home government. In contrast to investors' utilizing BITs or other treaties to impose costs on the host government, we would consider this type of lobbying and direct government to government punishment an exercise of investors' de facto power.

In addition to driving up the costs to the government $\left(C_{E}\right.$ and $\left.C_{T}\right)$, effective resistance by investors sometimes results in the recovery of some of the expropriated assets. This is particularly true of resistance based on de jure power. In the interest of parsimony, we do not model this recovery explicitly in the payoffs to the investor, but the addition of a recovery term into the model would not alter the comparative statics of interest. ${ }^{28}$ We consider this extension of the model a potentially fruitful avenue for future research.

We now explore how the ability to resist affects the political risk equilibrium. The blowback cost of transfer breach, $C_{T}$, affects when the government will choose an increase in transfer restrictions; it also affects when it will choose expropriation. Rewriting the $C_{T^{-}}$ condition in definition 1 for $\omega$, recall that $G$ will choose transfer restrictions when $\omega \leq$ $R \alpha(1-\mu)+\mu V \gamma\left(t_{0}+\tau\right)+C_{E}-C_{T}$. It is straightforward to see that, as $C_{T}$ increases, the right side of the inequality decreases, and the $C_{T}$-condition becomes more difficult to satisfy, making expropriation preferable over a larger range of investments. Will the same be true for $C_{E}$ ? Will it only affect the expropriation decision?

Notice from the model that each decision node accounts for both direct and indirect factors. While transfer risk often leaves an investment intact, outright expropriation does not; in our model, it is a final stop. Thus, while $C_{T}$ only affects the transfer risk decision, $C_{E}$ affects both the decision to increase transfer restrictions (through the $C_{T}$-condition) and,

\footnotetext{
${ }^{27}$ Such direct intervention by the home government has long been a focus of the political risk literature (e.g. Kindleberger 1969; Kahler 1984; Frieden 1994). While early work focused on colonial and neo-colonial relationships, a recent related literature is emerging around China's role in promoting and protecting outward FDI (e.g. Shi 2013).

${ }^{28}$ One could model recovered funds as some proportion of the initial investment. In the government payoffs, these funds could be separated from the rest of $C_{E}$ (and would show up as a reduction in the government payoffs from expropriation), while in the investor payoffs they would show up as a reduction in the investor loss from expropriation.
} 
ultimately, to expropriate or not (conditions 1 and 2). For condition (1), $\omega \geq R \alpha(1-$ $\mu)+\mu V \gamma t_{0}+C_{E}$, it is straightforward that as $C_{E}$ increases, the right side of the inequality increases, and condition (1) is more difficult to satisfy. Analogous to $C_{T}$ 's impact on transfer risk, increasing $C_{E}$ makes expropriation less preferable over a larger range of investments (the same obtains for condition 2). ${ }^{29}$

The $C_{T}$-condition, $\omega \leq R \alpha(1-\mu)+\mu V \gamma\left(t_{0}+\tau\right)+C_{E}-C_{T}$, is more nuanced. Here, $G$ decides between expropriation and increasing transfer restrictions (without expropriation). While increasing $C_{E}$ makes the $C_{T}$-condition easier to satisfy - as expected, increasing the costs of expropriation makes transfer restrictions more attractive, and increasing $C_{T}$ makes it more difficult to satisfy - again as expected, increasing the costs of transfer breach makes transfer restrictions less attractive, notice that $C_{E}$ and $C_{T}$ are oppositely signed. Thus, while $\left\{C_{E}>0, C_{T}=0\right\}$ and $\left\{C_{E}=0, C_{T}>0\right\}$ produce intuitive comparative statics results, what if a government will face costs in either scenario; what if $\left\{C_{E}>0, C_{T}>0\right\}$ ? Consider that, while it is possible that only one cost is nonzero, it is more often the case that costs, whether retaliatory or reputational, are triggered by either expropriation or transfer breach.

So what happens, in this more realistic case? Condition (1) is unaffected by this possibility: it only is affected by $C_{E}$. The $C_{T}$-condition however is affected. In this SPE, increasing $C_{T}$ reduces the subset of investments over which transfer restrictions are selected; however, if $C_{E}$ also increases, it undermines this risk mitigation for transfer risk. If $C_{E}$ rises as much as $C_{T}$, then there may be no effect or even an increased size of the subset over which $G$ will select transfer restrictions! If scholars only look at transfer risk, and the resistance costs associated, they might easily miss this nuance: that simply increasing the blowback costs associated with transfer breach does not mean that transfer breach is necessarily less likely! Indeed, once we consider other risks, and other costs, our logic demonstrates that the prevalence of transfer restrictions may even increase. This is particularly likely to be the case if the same types of investors that can mount effective resistance to transfer restrictions can also mount (even more) effective resistance to expropriation. In section 6.2 we argue

\footnotetext{
${ }^{29}$ Notice that increasing $C_{T}$ also makes condition 4 easier to satisfy, thus making the transfer breach option more feasible for $G$.
} 
that this is, in fact, a quite common set of conditions.

While the effect of $C_{T}$ on the willingness of $G$ to engage in transfer breach is conditional, the effect of $C_{E}$ on $G^{\prime}$ s willingness to expropriate is straightforward. Looking at both conditions (1), (2) and the $C_{T}$-condition, we see that, as both $C_{E}$ and $C_{T}$ increase, $G$ will be less likely to expropriate; whether they increase transfer restrictions or not! ${ }^{30}$ Thus, it may be that high $C_{E, T}$ (e.g. the ability to resist) is more valuable for investors that are more concerned about expropriation (e.g. direct investors).

This section continues the process begun in section 4. Parameters in the model correspond to the capabilities of investors; comparative statics from the model thus allow us to explore that full strategic implications of variations in investor capabilities. Direct investors may be dramatically, albeit indirectly, affected by other foreign investors, through the political risk profiles that governments select, in response to those other investors; being a minority investor may either entail a risk shield from the more predominant investor, or a greater barrier to entry; and increasing the blowback costs to all political risks, across the board, may not reduce all political risk, and may even increase transfer risk (both relatively and absolutely). While it may be tempting to take disparate intuitions like "FDI should be concerned with how a host treats other FDI" and "increasing costs of contract breach with help prevent that breach," and apply them more generally to our understanding of risk phenomena, this section argues that, to do so, would be too simplistic. Reality is more nuanced, and this section is a first attempt at making that nuance tractable.

\subsection{Level of Information}

Access to information - local and global, public and private - is a critical component of investors' competitive advantage (e.g. Hirshleifer 1971; Rumelt 1984; Vives 1990). To identify opportunities and assess risks, investors need information about: trends in the local and global economy; pending changes in the local and global policy environment; the structure of the local and global market; the identity and reliability of potential local and global busi-

\footnotetext{
${ }^{30}$ Meaning that, when expropriation is preferable, the equilibrium in Proposition 1 will be supportable only over a smaller subset of investments.
} 
ness counterparts; the preferences of relevant local and global elites; and a range of other issues. Public information is available to all investors in the market and can be obtained at relatively low cost, though only some may have the capacity to gather, translate, and analyze it. Private information is costlier to obtain and available to only some actors. Local information about a host country tends to favor local investors, whereas global information favors foreign (multinational) investors (Albuquerque, Bauer, and Schneider 2009).

In rich democracies, specifically, local public information about government policy and economic fundamentals is abundant and easily accessible from outside the country. However, in emerging markets government transparency is often low, with limited and unreliable economic data and press coverage, making local public information scarce (e.g. Hollyer, Rosendorff and Vreeland 2013; Adsera, Boix and Payne 2003). The only firms that can accurately identify opportunities and assess political risks are those with access to local private information. This makes local private information particularly valuable in emerging markets (e.g. Leuz and Oberholzer-Gee 2006)

In our model, the archetypical investor is assumed to have enough local private information to foresee transfer events, but not to foresee expropriation events. ${ }^{31}$ If an investor lacks sufficient information to foresee changes to transfer risk, expedited repatriation (e.g. exit, to be discussed in following section) becomes impossible and the value of $\epsilon$, the value of assets repatriated early, is forced to zero; the investor loses her ability to exit before the costly transfer breach. If a well-connected investor has sufficient private information to foresee expropriation (we believe this is very rare), then that investor would enjoy an option of costly repatriation similar to that we model for transfer risk. In practice, different types of foreign investors vary in their access to local private information, and therefore also vary in their ability to foresee adverse political events.

Among the four investor classes we discuss, foreign commercial banks possess the most local private information about the probability of changes to foreign exchange restrictions. Because banks tend have sizeable presences in the host country, both in terms of local

\footnotetext{
${ }^{31}$ See the following section on mapping investor capabilities to risk.
} 
branches and domestic exposures in local and foreign currency, they build deep relationships with political and economic elites who funnel non-public information and reveal policy preferences (Dinc 2005; Cohen 1996; Sengupta 2007; Faccio 2006). From their information intensive lending, foreign banks also gain detailed knowledge of and access to multiple parties across the local economy (Beim and Calomiris 2001).

Foreign direct investors are not as advantaged. Direct investors hold corporate control positions that offer privileged principal information about the firm or sector in which they are invested (Goldstein and Razin 2006), which is often augmented by in-depth knowledge of their particular investment and significant global private information about their product or business line. However, the average direct investors' local private information is limited in scope to either their firm or the relevant sector in which their firm operates. The willingness to develop broad political connections may be similar to that of banks, particularly to the extent the direct investor is resource-seeking, yet direct investors' abilities are typically limited due to the circumscribed nature of their engagement across the host economy.

In contrast to banks and even direct investors, the average portfolio debt and equity investors are large institutional investors with high levels of global information but low levels of local information (Albuquerque, Bauer, and Schneider 2009). Their advantage lies in information about market benchmarks, relative value, future investment trends, and upcoming interest rate changes in advanced countries; in short, information about the "push" factors that explain much of variance in capital flows into emerging markets. But these investors have neither the country-specific experience nor the ongoing access to local elites necessary to obtain local private information. Indeed, portfolio debt and equity typically function without any domestic presence, short of an institutional prime broker that executes the trade. This lack of local information explains much of the tendency of portfolio debt and equity flows to exhibit "herding" behavior where investors cue off of a first-mover with (possibly) superior knowledge (e.g. Shleifer and Summers 1990; Lux 1995; Avery and Zemsky 1998; Banerjee 1992). 


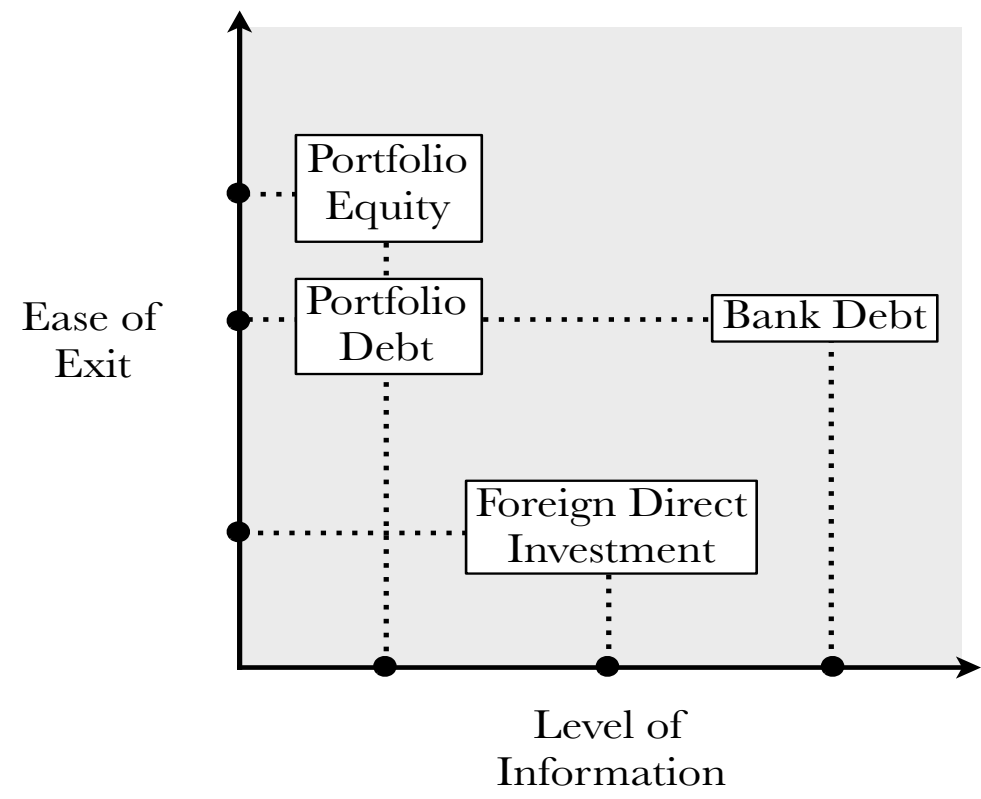

Figure 4: Summary of Investor Types. A classification of foreign investors by two capabilities: level of local private information (horizontal axis) and ease of exit (vertical axis).

\subsection{Ease of Exit}

Ease of exit refers to investors' ability to cheaply and rapidly shift assets out of the host country. Ease of exit is a necessary condition for investors to be able to move assets before losses are incurred, but it is not sufficient. Investors also need to know that that an adverse event is pending - hence the importance of level of information, discussed above. In the model, ease of exit is reflected in the value of $\lambda$, which is the costs of early repatriation to investors. High ease of exit equates to low costs of expedited repatriation (i.e. low values of $\lambda)$.

Ease of exit varies across investors according to the liquidity of an investor's stake, the investor's time horizon, and the physical mobility of the underlying assets. The liquidity of an investor's stake determines her ability to sell that stake before losses are realized; the investor's time horizon determines whether early liquidation of assets will induce losses and whether losses can be avoided by "waiting out" the adverse event; and the physical mobility of the underlying assets determines whether an investor can move assets out of harm's way. 
The liquidity of investor stake varies substantially across classes of investor. Direct investors are the least liquid because they typically own large shares of the enterprise in question and are involved in management of the firm in which they are invested (Vernon 1971; Goldstein and Razin 2006). Investments by foreign banks are markedly more liquid. Banks have the capability to halt loans in progress and cancel future borrowings; in certain circumstances they also have the right to accelerate outstanding loans (Graham, Johnston, and Kingsley 2014). Lastly, portfolio debt and portfolio equity are the most liquid because they are traded in open markets. ${ }^{32}$ Portfolio equity markets are larger and deeper than public (or private) debt markets, giving equity investors the highest levels of liquidity.

The physical immobility of assets is central to the "obsolescing bargain" in which foreign investors become vulnerable to host-government predation once costs have been sunk into immobile assets such as mines or factories (Kindleberger 1969; Kobrin 1970). However, as Kerner and Lawrence (2014) demonstrate, even foreign direct investors (whose stakes are illiquid) are capable of avoiding many political risks if the underlying assets they own are not fixed. In other words, a direct investor whose assets are primarily intangible (such as accounts receivable) or mobile (such as product inventory) has high ease of exit. Empirically, this fixity can be approximated by measuring plants, property, and equipment (PPE) as a share of total affiliate assets, and this PPE share varies dramatically by sector. For example, among the overseas affiliates of U.S. multinationals, PPE accounts for half or more of total assets among mining and utilities firms, while accounting for only $6-7 \%$ of total assets in the services and wholesale sectors (Kerner and Lawrence 2014: 115).

It is noteworthy that the ability of investors to shift assets out of the host country before losses are incurred (a product of investors' ease of exit and access to information), is equivalent to the inability of the host government to successfully seize assets from those investors. Thus, investors' ability to avoid the consequences of an attempted seizure of wealth deters the government from making that attempt.

Due to space constraints, we do not examine the comparative statics with regard to

\footnotetext{
${ }^{32}$ See the discussion in the literature on hot capital, e.g. Calvo, Leiderman, and Reinhart 1996
} 
information and liquidity (i.e. value of $\lambda$ ) in the same degree of detail that we devote above to variations in resistance capabilities. We relegate this analysis to related work (Graham, Johnston, and Kingsley, 2015).

\section{Mapping Capabilities to Risks}

In the sections above, we outline how foreign investors vary in their capabilities for managing political risk. However, some capabilities are more relevant for certain types of political risk than for others. By mapping different capabilities onto the risks they are most effective at managing, we can develop detailed theory regarding how an investor's capabilities shape the universe of host countries in which they can operate effectively and, conversely, how a country's political risk profile affects the type, as well as the volume of inward investment it attracts. It is important to note at the outset of this section that our mapping of firm capabilities to specific risks does not exhaust all political risk management strategies available to firms. For example, one of the implications of our model is that investors can limit their vulnerability to expropriation risk by assessing the political valence of the assets in which they invest and selecting assets that have relatively little value to the government (i.e. assets for which $\omega$ is small). Thus, not all political risk management strategies depend on the three capabilities we explore, but we expect these three capabilities explain a substantial portion of the variation in firms' political risk vulnerability.

\subsection{War vs. Expropriation \& Transfer Restriction}

War risk is unique in that it is not a deliberate strategy by the host government to extract wealth from foreign investors; in terms of the implicit contract, it is simply a failure to uphold the government's commitment to protect the investor's property and personnel from violence. Thus, war cannot be effectively mitigated by strategies based on resistance

- war is already not the government's most preferred outcome and it is unlikely even very capable investors can prevent a war from occurring.

We acknowledge that in certain narrow contexts, mitigation of war risk by select in- 
vestors is possible. For example, foreign investment in oil extraction in the Niger delta continued (sometimes profitably) in the face of high levels of violence throughout the 1990s, with firms investing heavily in a range of active risk mitigation strategies, including private security forces. However, these high-cost efforts are generally limited to investors engaged in high-margin natural resource extraction (Graham 2014).

Information-based strategies are similarly limited in the context of war. Investors who carefully analyze local public information may have a more precise estimate of the underlying probability of war than those who do not, but the relevant local private information is unlikely to be available to even the most connected investor. Military strategy - e.g. when and where fighting will occur - is a carefully guarded secret generally unavailable even to most political elites. This levels the playing field between investors with and without access to local private information.

While exit is the most productive, and usually the only, option available to foreign investors to mitigate war risk, ease of exit itself is endogenous to the presence of war. War can cause markets to freeze and borders to close. Previously liquid stakes become illiquid; previously mobile underlying assets become immobile.

Thus, war is cataclysmic. It is the archetypical exogenous hazard. This is reflected in the force majeure clauses of most commercial contracts which explicitly carve out war as an extraordinary and unforeseeable event beyond the control of either party, akin to acts of God like fire, floods, earthquakes, and hurricanes.

Of course, to argue that investor capabilities are largely irrelevant is not to argue that exposure to war risk does not vary across firms. For example, investors with larger and more dispersed physical footprints in the host country are more vulnerable - they have more physical property in more places that can be destroyed, more personnel that can be injured or killed. Similarly, investors that are more infrastructure-dependent are more likely to be harmed when that infrastructure is destroyed (Collier 1999). But these sources of variation are not a reflection of capabilities, per se. 


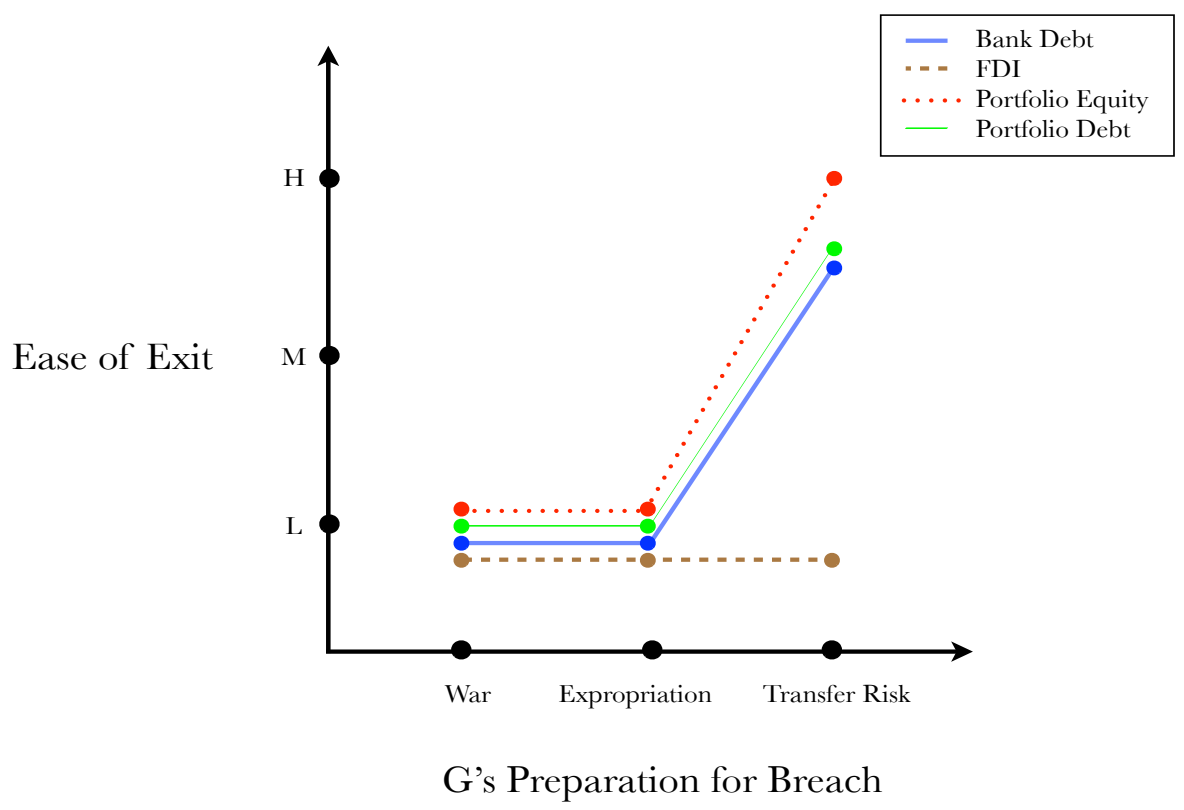

Figure 5: Summary of investor ease of exit, by type of risk. Here, the ease to exit is ordered as low $(L)$, medium $(M)$, and high $(H)$, and risk is ordered by how intensively a government prepares prior to the breach.

\subsection{Transfer Risk vs. Expropriation}

Strategies of resistance are more effective when the actions of the government are universally accepted as violations of investor property rights. In this context, it is easy to coordinate the domestic public and foreign investors (including those not directly harmed) to collectively punish the government. Coordinated resistance raises the costs of blowback, deterring the host government from taking adverse action in the first place. 


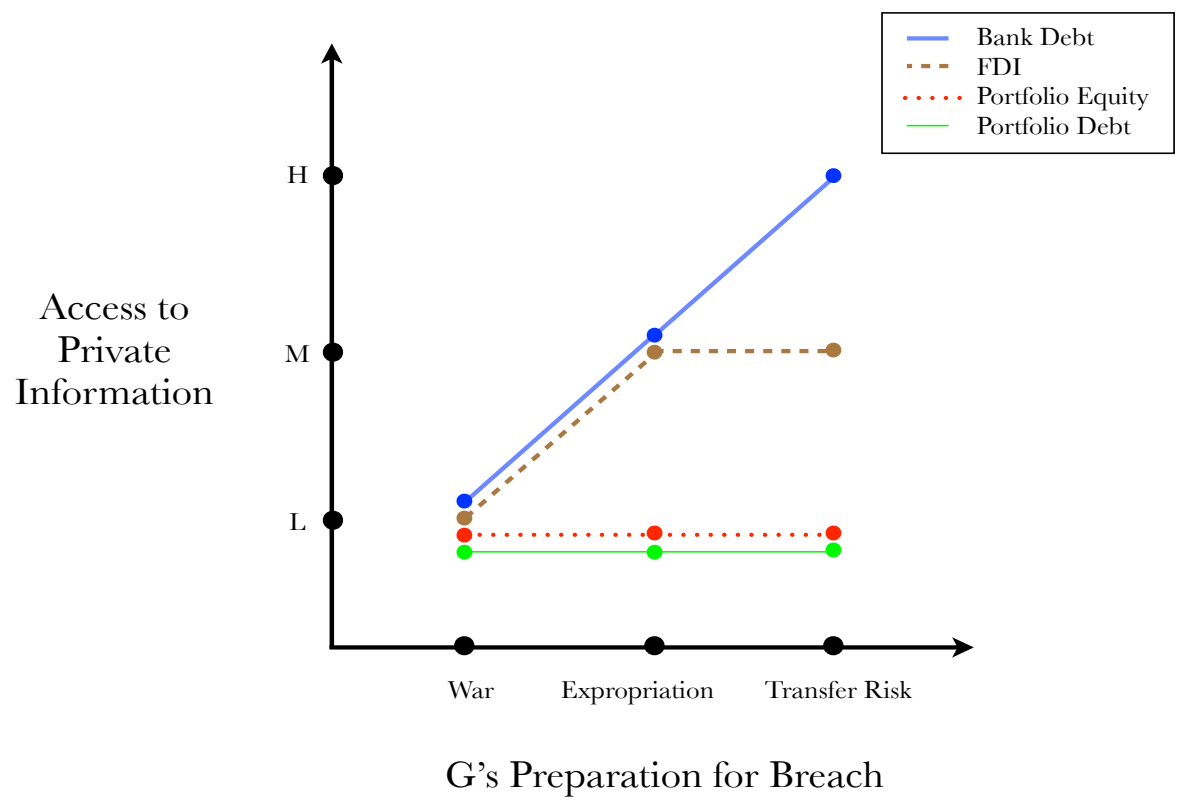

Figure 6: Summary of investor access to private information about the investment climate, by type of risk. Here, the ease to exit is ordered as low $(L)$, medium $(M)$, and high $(H)$, and risk is ordered by how intensively a government prepares prior to the breach.

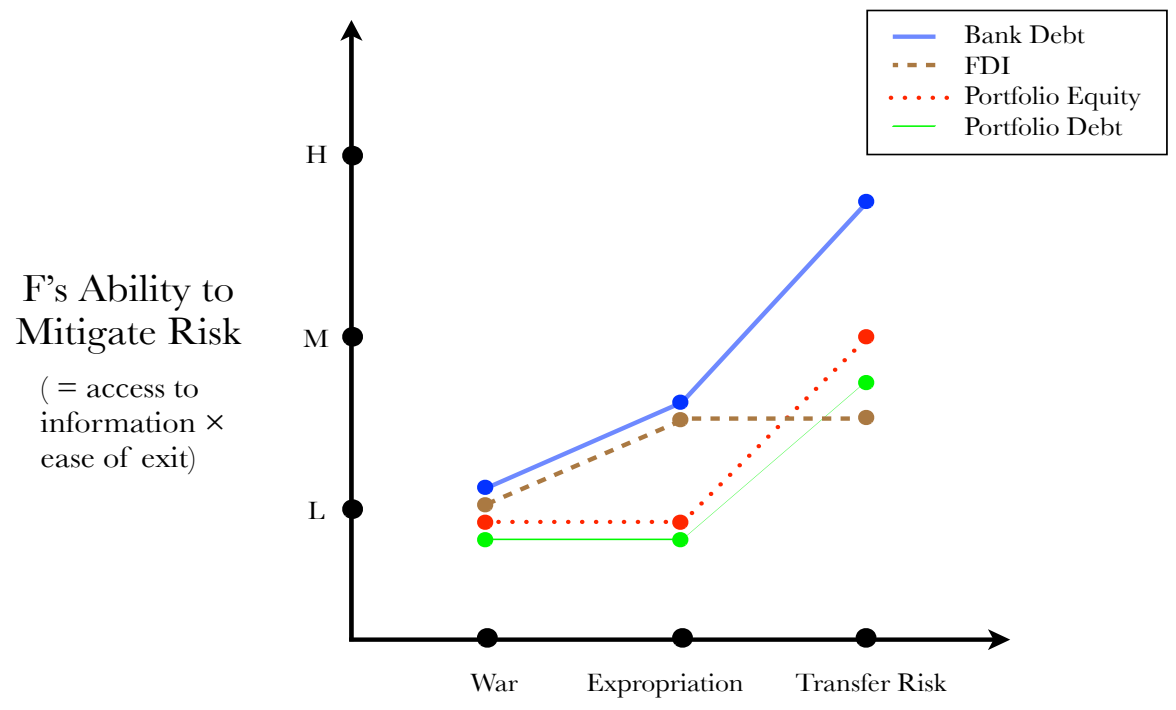

G's Preparation for Breach

Figure 7: Summary of investor ability to mitigate risk, by type of risk. Here, ability to mitigate risk is a composite of an investor's ability to exit quickly and their level of private information. It is ordered as low $(L)$, medium $(M)$, and high $(H)$. Risk is ordered by how intensively a government prepares prior to the breach. Notice that the more steps the government must take (i.e. the more comprehensive their preparation), the more ability investors have - in general - to reduce the expected cost of the breach. 
As noted earlier in the paper, the right of foreign investors to be free from expropriation is accepted nearly universally, while the right to be free from transfer restriction remains contested. If the transfer restrictions become more broadly accepted as violations of investor property rights, then $C_{T}$ will increase, investors' resistance capabilities will become more effective in reducing transfer risk, and ex post recovery of investor losses will become more common. In the meantime, transfer restrictions remain common and we expect that investors' ability to engage in effective strategies of resistance remains limited. This is in stark contrast to expropriation, against which we expect investor resistance to be more effective.

Note that these factors - that resistance by capable investors is likely to increase $C_{E}$ than $C_{T}$ is precisely the condition we discussed in section 4.1. Under these conditions, an increase in $C_{T}$ is not necessarily associated with a decrease in the range of conditions under which transfer breach will occur. In related work, we test whether domestic political constraints, which increase the accountability of the government to the domestic public, are effective in reducing political risk. Consistent with the theory outlined here, we find that political constraints reduce expropriation risk but not transfer risk (CITATION REDACTED TO PRESERVE ANONYMITY).

Hypothesis 1: Resistance is more effective at deterring governments from engaging in expropriation than from imposing transfer restrictions.

Access to private information is potentially valuable in managing both expropriation and transfer risk, but more valuable in managing transfer risk. As noted previously, imposing economy-wide transfer restrictions requires coordination across multiple branches of government. The government attempts to keep pending transfer restrictions secret, and this need to involve so many political actors in the decision-making process allows wellconnected investors (i.e. investors with access to local private information) to learn of pending transfer restrictions before they occur. Thus, investors with access to private information can anticipate transfer restrictions, those reliant on public information cannot.

In contrast, the expropriation of assets from a single investor can be accomplished by a 
single government entity with little outside coordination and is therefore much easier for the government to keep secret until it occurs. Even investors with high levels of private information are unlikely to see it coming. This renders access to private information much less valuable in managing expropriation than in managing transfer risk.

Hypothesis 2: Information is more useful in managing transfer risk than in managing expropriation risk.

If investors cannot gain information about pending expropriation events, then investors' ease of exit is rendered less relevant - you can't flee what you can't see coming. We model the extreme case: if the government chooses to expropriate, then the investor loses the full value of her investment, regardless of capabilities. Partial ex post recovery of losses is possible, but ex ante repatriation of assets is not.

Hypothesis 3: Exit is more effective at mitigating transfer risk than expropriation or war risk.

To summarize, An investor's exposure to expropriation risk is primarily a product of the investor's resistance capabilities. An investor's exposure to transfer risk, on the other hand, is affected by ease of exit (liquidity of stake, time horizons), information, and resistance. This renders transfer risk the most interesting subject of academic study: the losses it imposes on foreign investors are large and growing, and investors' abilities to manage it vary across several different dimensions. Conversely, war risk is a purely exogenous hazard and investor capabilities are largely irrelevant - few if any investors can manage war risk effectively. 
Classifying Risk by Amenability to Investor Capability

\begin{tabular}{|l|c|c|}
\cline { 2 - 3 } \multicolumn{1}{c|}{} & $\begin{array}{c}\text { information- } \\
\text { sensitive }\end{array}$ & $\begin{array}{c}\text { not information- } \\
\text { sensitive }\end{array}$ \\
\hline $\begin{array}{l}\text { resistence- } \\
\text { sensitive }\end{array}$ & transfer risk & expropriation \\
\hline $\begin{array}{l}\text { not resistence- } \\
\text { sensitive }\end{array}$ & & war \\
\hline
\end{tabular}

Figure 8: This table categorises risks by the degree to which they can be mitigated via resistance or and information. Information here refers to access to private information and ease of exit jointly.

\section{Conclusion}

Traditional analyses of political risk examine a single risk and a single type of investor. In this paper, we bring together multiple risks and investor types into a unified model, and we find reason to believe that the insights derived from piecemeal analyses can be misleading. Direct investors may be dramatically affected by other classes of investor, through the risk environment that a government cultivates around those investors; increasing a firm's capacity to resist breaches of the implicit contract does not necessarily reduce that firm's vulnerability to all political risks, and sometimes it may increase transfer risk (both relative to expropriation, and absolutely); sometimes it is not the most predominant investor class that is safest, but the minority investor that can use the majority as a risk shield. Without looking at multiple risks, multiple investors, and multiple types of risk-mitigation strategies, even simple insights like these may go unseen, unintegrated into our theories, and thus unaccounted for when trying to understand how political risk affects foreign investment, and our globalizing world, more generally.

In developing a formal model of risks, investors, and capabilities, this paper aims to generate precise and falsifiable predictions about investment in emerging markets. We construct our model from: a more realistic conceptualization of the complexity of political risk; 
the universe view of private capital investors; and a broader assessment of the capabilities investors employ to shield themselves from predatory, or simply unfortunate, host government behavior. Introducing this simultaneous model allows scholars to better understand the counterintuitive trade-offs governments make between types of "sovereign theft" and the costly trade-offs investors make with regard to their location decisions and the allocation of strategic resources.

On governments, our model shows that the traditional focus on political constraints as an effective deterrent of "sovereign theft" is flawed. Even if political constraints raise the costs of transfer breach, they may not reduce the range of conditions under which transfer breach will occur. In more democratic countries with higher levels of political constraints, outright expropriation is a rare event but transfer and convertibility restrictions are increasing and common. Political risk is not absent in these regimes; it just occurs in altered form.

This work also has important implications for strategic management scholars studying the firm. Although we focus heavily on the capabilities associated with different classes of foreign capital (i.e. direct, portfolio equity, portfolio debt, and bank debt investors), the model is directly relevant to analyzing firm-level risk exposure and predicting firm strategic behavior. Firms must assess their relative endowment of capabilities, some of which may be severely constrained, to determine what advantages they possess relative to competitors. If a firm has significant information abilities ("smart" firms), perhaps born from previous experience or political connections, entering markets with significant levels of transfer risk give it a competitive advantage in opaque and non-transparent countries. Firms with liquid assets and low levels of fixed property, plants, and equipment ("hot" firms) may also be advantaged in such countries, yet without information they are prone to making the costly error of rushing to exit before they know there's a fire. Conversely, a firm with the ability to resist and retaliate against host country predation ("strong" firms), perhaps due to significant home country political support or capabilities to put pressure on the host government, stands to gain from doing business in expropriation-risky countries, which are typically 
shunned by firms less endowed. A more extreme case is that miniscule pool of investors with unique, highly sophisticated capabilities to manage war risk; such investors should enter war-risky countries in which they will be effectively awarded monopolies.

Drawing more directly on our model, our work further suggests that firms must evaluate their relative position in the investor pool. For instance, if direct investors observe that they are primarily surrounded by portfolio debt and equity investors, they should be forewarned that transfer risk is elevated, even as expropriation risk may be diminished. If banks identify that the host economy is overpopulated with direct investors relative to them, their transfer risk exposure decreases and the other investors effectively act as a risk shield. In many ways, political risk is endogenous to the capabilities of the current population of foreign investors operating in the host economy, providing opportunities for much more sophisticated risk assessment and opportunistic behavior by firms. Counterintuitively, there can be value in being unimportant to the host government.

Thus, this unified model of political risk provides the necessary theoretical foundation upon which to build a more nuanced and relevant analysis of political risks, foreign investors, and strategic capabilities. The next steps in the research program are to empirically test the theory using both country-level capital flows data and firm-level data. We seek a predictive applied model of global political risk. 


\section{Acknowledgements}

We acknowledge helpful comments from the editors, two anonymous reviewers, and panel participants at the American Political Science Association Annual Meeting in Washington, D.C., August 2014.

\section{Biographies}

Benjamin A.T. Graham (Ph.D., University of California, San Diego) is Assistant Professor of International Relations at the University of Southern California. His core research agenda is on the role of foreign investment in the stabilization and development of fragile states. He also serves as a Special Sworn Researcher at the U.S. Bureau of Economic Analysis.

Noel P. Johnston (Ph.D., Washington University in St. Louis) is Postdoctoral Fellow at Oxford University's Blavatnik School of Government. His research focuses on the structure of compliance with international property rights in foreign investment markets.

Allison F. Kingsley (Ph.D., Columbia University) is Assistant Professor at the University of Vermont's School of Business Administration. Her research focuses on investor strategies to manage political risk in emerging markets. For ten years she worked on Wall Street for banks and buy-side funds. 


\section{References}

1. Acemoglu, D. and Robinson, J.A. (2006). De Facto Political Power and Institutional Persistence. AEA Papers and Proceedings. 96(2): 325-330.

2. Adserà, A., Boix, C., and Payne, M. (2003). Are You Being Served? Political Accountability and Quality of Government. Journal of Law, Economics, and Organization 19 (2): $445-90$.

3. Albuquerque, R., Bauer, G., and Schneider, M. (2009). Global Private Information in International Equity Markets. Journal of Financial Economics 94 (1): 18-46.

4. Alston, L.J., Harris, E., and Mueller, B. (2008). De Facto and De Jure Property Rights: Land Settlement and Land Conflict on the Australian, Brazilian and U.S. Frontiers. NBER Working Paper 15264.

5. Anderson, E., and Gatignon, H. (1986). Modes of Foreign Entry: A Transaction Cost Analysis and Propositions. Journal of International Business Studies 17(3): 1-26.

6. Avery, C., and Zemsky, P. (1998). Multidimensional Uncertainty and Herd Behavior in Financial Markets. The American Economic Review 88 (4): 724-48.

7. Banerjee, A. V. (1992). A Simple Model of Herd Behavior. The Quarterly Journal of Economics 107 (3): 797-817.

8. Baron, D. (2001). Private Politics, Corporate Social Responsibility, and Integrated Strategy. Journal of Economics and Management Strategy 10(1): 7-45.

- (1995). Integrated Strategies: Market and Nonmarket Components. California Management Review 37(2): 47-65.

9. Beim, D, and Calomiris, C. (2000). Emerging Financial Markets. First edition. Boston: McGraw-Hill/Irwin.

10. Brouthers, K. D. (2002). Institutional, Cultural, and Transaction Cost Influences on Entry Mode Choice and Performance. Journal of International Business Studies 33(2): 203-221. 
11. Bonardi, J.P., Hillman, A.J. and Keim, GD. (2005). The Attractiveness of Political Markets: Implications for Firm Strategy. Academy of Management Review 30: 397-413.

12. Broz, L. and Frieden, J. (2006). The Political Economy of Exchange Rates. In Oxford Handbook of Political Economy. Edited by Barry Weingast and Donald Wittman. Oxford: Oxford University Press.

13. Bueno de Mesquita, B., Smith, A., Siverson, R., and Morrow, J. (2003). The Logic of Political Survival. Cambridge, MA: MIT Press.

14. Calvo, G., Leiderman, L., and Reinhart, C. (1996). Inflows of Capital to Developing Countries in the 1990s. The Journal of Economic Perspectives 10 (2): 123-39.

15. Cohen, B. (1996). Phoenix Risen: The Resurrection of Global Finance. World Politics, 48, 268-296.

16. Collier, R. (1999). Paths Toward Democracy: The Working Class and Elites in Western Europe and South America. Cambridge, United Kingdom: Cambridge University Press.

17. Deere, C. (2008). Implementation Game: The TRIPS Agreement and the Global Politics of Intellectual Property Reform in Developing Countries. Oxford, GBR: OUP Oxford.

18. Delios, A., and Henisz, W. (2003). Political Hazards, Experience, and Sequential Entry Strategies: The International Expansion of Japanese Firms, 1980-1998. Strategic Management Journal 24 (11): 1153-64.

19. Delios, A. and Beamish, P.W. (2001). Survival and Profitability: The Roles of Experience and Intangible Assets in Foreign Subsidiary Performance. Academy of Management Journal 44(5): 1028-1038.

20. Dinc, S. (2005). Politicians and Banks: Political Influences on Government-Owned Banks in Emerging Markets. Journal of Financial Economics 77(2): 453-479.

21. Emmons, W. (2000). The Evolving Bargain: Strategic Implications of Deregulation and Privatization. Cambridge, MA: Harvard Business School Press. 
22. Faccio, M. (2006). Politically Connected Firms. The American Economic Review 96 (1):36986.

23. Fang, S., and Owen, E. 2011. "International Institutions and Credible Commitment of Non-Democracies." The Review of International Organizations 6: 141-62.

24. Fearon, J. (1995). Rationalist Explanations for War. International Organization 49 (3):379414.

25. Frieden, J.A. (1994). International Investment and Colonial Control: A New Interpretation. International Organization 48 (4): 559-93.

26. Ghobarah, H., Huth, P., and Russett, B. (2003). Civil Wars Kill and Maim People-Long after the Shooting Stops. The American Political Science Review 97 (2): 189-202.

27. Goldstein, I., and Razin, A. (2006). An Information-Based Trade off between Foreign Direct Investment and Foreign Portfolio Investment. Journal of International Economics 70 (1): 271-95.

28. Graham, B. (2014). Political Risk and New Firm Entry. Available at SSRN: http://ssrn.com/abstract=21661?

29. Graham, B., Johnston, N., and Kingsley, A. (2015). Even Constrained Governments Steal: The Domestic Politics of Transfer and Expropriation Risks. Presented at the 2013 Annual Strategy and the Business Environment Conference. Austin, Texas. Available at http:/ / papers.ssrn.com/sol3/papers.cfm?abstract_id=2106621

30. Graham, B., Johnston, N., and Kingsley, A. (2014). “Capital Flows and Political Risk. Available at http:/ / ssrn.com/abstract=2533651

31. Hadfield, G., and Weingast, B. (2013). Law without the State: Legal Attributes and the Coordination of Decentralized Collective Punishment. Journal of Law and Courts 1 (1): 3-34.

- (2012). What Is Law? A Coordination Model of the Characteristics of Legal Order. Journal of Legal Analysis 4 (2): 471-514. 
32. Hegre, H. (2004). The Duration and Termination of Civil War. Journal of Peace Research 41 (3): $243-52$.

33. Hennart, J.F. (2009). Down with MNE-centric Theories! Market Entry and Expansion as the Bundling of MNE and Local Assets. Journal of International Business Studies 40(9): 1432-1454.

34. Henisz, W. (2000). The Institutional Environment for Economic Growth. Economics and Politics 12: 1-31.

35. Henisz, W., and Zelner, B. (2010). The Hidden Risks in Emerging Markets. Harvard Business Review 88 (4): 88-95.

- (2005). Legitimacy, Interest Group Pressures, and Change in Emergent Institutions: The Case of Foreign Investors and Host Country Governments. Academy of Management Review 30 (2): 361-382.

36. Henisz, W., Dorobantu, S., and Nartey, L. (2013). Spinning Gold: The Financial Returns to Stakeholder Engagement. Strategic Management Journal 35(12): 1727-1748.

37. Hillman, A. J. and Hitt, M. (1999). Corporate Political Strategy Formulation: A Model of Approach, Participation, and Strategy Decisions. Academy of Management Review 24(4): 825-842.

38. Hirshleifer, J. (1971). The Private and Social Value of Information and the Reward to Inventive Activity." The American Economic Review 61: 561-74.

39. Hollyer, J., Rosendorff, B., and Vreeland, J. (2014). Measuring Transparency. Political Analysis 22(4): 413-434.

40. Jensen, N. (2006). Nation States and the Multinational Corporation: A Political Economy of Foreign Direct Investment. Princeton: Princeton University Press.

- (2003). Democratic Governance and Multinational corporations: Political Regimes and Inflows of Foreign Direct Investment. International Organization 57(3): 587-616. 
41. Johnston, N. (2015). Political Risk and RealPolitik: The Politics of Compensation for Expropriation. Available at: http://papers.ssrn.com/sol3/papers.cfm?abstract_id=2134577.

42. Kahler, M. (1984). Decolonization in Britain and France: The Domestic Consequences of International Relations. Princeton: Princeton University Press.

43. Kerner, A., and Lawrence, J. (2014). Whats the Risk? Bilateral Investment Treaties, Political Risk and Fixed Capital Accumulation. British Journal of Political Science 44 (1): 107-21.

44. Khanna, T., Palepu, K., \& Bullock, R. (2010). Winning in Emerging Markets: A Road Map for Strategy and Execution. Boston: Harvard Business Review Press.

45. Kindleberger, C. (1969). American Business Abroad. New Haven, CT: Yale University Press.

46. Kingsley, A., Vanden Bergh, R., and Bonardi, J. (2012). “Political Markets and Regulatory Uncertainty: Insights and Implications for Integrated Strategy." Academy of Management Perspectives 26(3): 52-67.

47. Kingsley, A., and Vanden Bergh, R. (2015). “How Regulatory Uncertainty Drives Integrated Strategy and Non-market Strategy," in The Routledge Companion to Non-market Strategy, ed. T. Lawton and T. Rajwani. London: Routledge, 47-65.

48. Kobrin, S. (1984). Expropriation as an Attempt to Control Foreign Firms in LDCs: Trends from 1960 to 1979. International Studies Quarterly 28 (3): 329-48.

_-(1979). Political Risk: A Review and Reconsideration. Journal of International Business Studies, 67-80.

49. Li, Q. and Resnick, A. (2003). Reversal of Fortunes: Democracy, Property Rights, and Foreign Investment Inflows in Developing Countries. International Organization 57(1): $1-37$.

50. Leuz, C., Oberholzer-Gee, F. (2006). Political relationships, global financing, and Corporate Transparency: Evidence from Indonesia. Journal of Financial Economics 81: 411-439. 
51. Lux, T. (1995). Herd Behaviour, Bubbles and Crashes. The American Economic Journal 105: 881.

52. Maitland, E. and Sammartino, A. (2014). Decision Making and Uncertainty: The Role of Heuristics and Experience in Assessing a Politically Hazardous Environment. Strategic Management Journal 27: 149-189.

53. Markus, S. (2012). Secure Property as a Bottom-Up Process: Firms, Stakeholders, and Predators in Weak States. World Politics 64 (2): 242-77.

54. Minor, M. (1994). The Demise of Expropriation as an Instrument of LDC Policy, 19801992. Journal of International Business Studies 25 (1): 177-88.

55. Oetzel, J., and Getz, K. (2012). Why and How Might Firms Respond Strategically to Violent Conflict? Journal of International Business Studies 43 (2):166-86.

56. Olson, M. (1965). The Logic of Collective Action: Public Goods and the Theory of Collective Action. Cambridge, Mass: Harvard University Press.

57. Rose-Ackerman, S., and Tobin, J. (2009). Do BITs Benefit Developing Countries? In The Future of Investment Arbitrations, eds. R.P. Alford and C.A. Rogers. Oxford: Oxford University Press.

58. Rumelt, R.P. (1984). Toward a Strategic Theory of the Firm." In Competitive Strategic Management, ed. R. Lamb. Englewood Cliffs, NJ: Prentice Hall. 556-70.

59. Sengupta, J. (2007). Dynamics of Entry and Market Evolution. Palgrave Macmillan.

60. Shi, W. (2013) Risky Business: A Firm-Level Analysis of Chinese Outward Direct Investment. Paper presented at the International Political Economy Society Conference, Claremont, CA, October 25-26, 2013.

61. Shleifer, A., and Summers, L. (1990). The Noise Trader Approach to Finance. Journal of Economic Perspectives 4: 19-33. 
62. Vernon, R. (1971). Sovereignty at Bay: The Multinational Spread of U.S. Enterprises. New York: Basic Books.

63. Vives, X. (1990). Information and Competitive Advantage." International Journal of Industrial Organization 8: 17-35.

64. Wellhausen, R. (2013). Investor-State Disputes: When Can Governments Break Contracts? Journal of Conflict Resolution.

- (2014). The Shield of Nationality: When Governments Break Contracts with Foreign Firms. New York, NY: Cambridge University Press.

65. Weingast, B. (1995). The Economic Role of Political Institutions: Market-Preserving Federalism and Economic Development. Journal of Law, Economics, and Organization. 11(1): 1-31.

66. Weston, B. (1975). Constructive Takings under International Law: A Modest Foray into the Problem of Creeping Expropriation. Virginia Journal of International Law 16: 103.

67. World Bank (2014). World Investment and Political Risk 2013. Washington, D.C.: The World Bank. 


\section{A Online Appendix}

\section{Proof of Proposition 1}

Using the process of backwards induction, we begin with the final move of the game; the government's expropriation decision. First, assume that the investor $(F)$ does not expedite the repatriation of his capital $(\epsilon=0)$ (we provide this condition below).

Suppose the government $(G)$ chooses transfer breach $\left(t^{\prime}\right)$. $G$ will play $\neg E$ when his payoff for expropriation $\left(\omega-C_{E}-C_{T}\right)$ is less than his payoff for not expropriating $(R \alpha(1-\mu)+$ $\left.V \gamma \mu\left(t^{\prime}(1-\epsilon)+t_{0} \epsilon\right)-C_{T}\right)$. Solving for $\omega$, and substituting $\epsilon=0$, this condition reduces to:

$$
\omega \leq R \alpha(1-\mu)+V \gamma \mu t^{\prime}+C_{E} .
$$

Suppose that the government chooses $t_{0}$, instead. $G$ will play $E$ when his expropriation payoff $\left(\omega-C_{E}\right)$ is greater than his payoff for not expropriating $\left(R \alpha(1-\mu)+V \gamma \mu t_{0}\right)$. Solving for $\omega$, this condition reduces to:

$$
\omega \geq R \alpha(1-\mu)+V \gamma \mu t_{0}+C_{E} .
$$

Notice that, because $t^{\prime} \geq t_{0}$, this condition will be always be consistent with condition 1 . Working backwards, we look at the investors decision to expedite his repatriation at level $\epsilon$.

The investor will select the amount to expedite which maximizes his expected payoff. While $G$ knows his transfer policy $(t)$ before it goes into effect, $F$ only sees a probability $p$ of a change to $t^{\prime}$. If $G$ does not change transfer policy, $F$ will always prefer not to expedite repatriation:

$$
\frac{\partial}{\partial \epsilon}(-V) \leq 0
$$

(which is satisfied: $0 \leq 0$ ). If $G$ instead plays $t^{\prime}, F^{\prime}$ s preference is conditional. For this $\mathrm{SPE}$, we are looking for a condition under which $F$ will play $\epsilon=0$. We see that increasing $\epsilon$ decreases $F^{\prime}$ s payoff $\left(V \gamma(1-\mu)+V \gamma \mu\left[\left(1-t^{\prime}\right)(1-\epsilon)+\left(1-t_{0}\right) \epsilon\right]-\lambda \epsilon\right)$ when the first 
derivative with respect to $\epsilon$ is negative. Solving for $\lambda$, this reduces to:

$$
\lambda \geq V \gamma \mu \tau
$$

Thus, when $\lambda \geq V \gamma \mu \tau, \epsilon=0$ is optimal, regardless of $p$ !

Continuing the backwards induction, with $G$ playing $\neg E$ following $t^{\prime}$ and $E$ following $t_{0}$, and $F$ selecting $\epsilon=0$ (for both cases), we now look at $G^{\prime}$ s choice of transfer policy. He will choose $t^{\prime}$ when the payoff for playing $t_{0}\left(\omega-C_{E}\right)$ is less than the payoff for playing $t^{\prime}$ $\left(R \alpha(1-\mu)+V \gamma \mu t^{\prime}-C_{T}\right)$. Solving for $C_{T}$, the condition reduces to:

$$
C_{T} \leq R \alpha(1-\mu)+V \gamma \mu t^{\prime}+C_{E}-\omega
$$

Solving this condition for $\omega$, we find: $\omega \leq R \alpha(1-\mu)+V \gamma \mu t^{\prime}+C_{E}-C_{T}$. Notice that this will be consistent with condition (2) (because $C_{T} \geq 0$ ), but will only be consistent with condition (3) when $R \alpha(1-\mu)+V \gamma \mu t^{\prime}+C_{E}-C_{T} \geq R \alpha(1-\mu)+V \gamma \mu t_{0}+C_{E}$. Solving for $C_{T}$, this condition reduces to:

$$
C_{T} \leq V \gamma \mu \tau
$$

Working backwards, Nature moves and determines a value for $C_{T}$. F does not see this move for sure; he sees a $p$-likelihood of condition (5) being satisfied. Then, working backwards again, Nature determines whether or not war occurs. $F$ does not see this move for sure: he sees an $r$-likelihood of war. Finally, with conditions (2), (3), (4), (5), and (6), we now analyze the first move of the game: $F^{\prime}$ s decision to invest or not.

$F$ faces a $C_{T}$-lottery and a war-lottery. He will play $I$ when his expected payoff for investing is greater than his break-even point of not investing (0). Given the probabilities of transfer breach $(p)$ and war $(r)$, and the expectation of the moves above, $F^{\prime}$ s expected payoff for investing is thus a composite of two weighted averages: 1) of his payoff in the case of transfer breach $\left(V \gamma(1-\mu)+V \gamma \mu\left(1-t^{\prime}\right)\right)$ and no breach $(-V): p[V \gamma(1-\mu)+$ $\left.V \gamma \mu\left(1-t^{\prime}\right)\right]+(1-p)(-V)$, and 2$)$ of his payoff in the case of war $(r[(1-q) V(\gamma-c)-q V])$ 
and no war $\left([1-r]\left[p\left[V \gamma(1-\mu)+V \gamma \mu\left(1-t^{\prime}\right)\right]+(1-p)(-V)\right]\right)$. Altogether, his expected payoff of investing is: $(r[(1-q) V(\gamma-c)-q V])+\left([1-r]\left[p\left[V \gamma(1-\mu)+V \gamma \mu\left(1-t^{\prime}\right)\right]+\right.\right.$ $(1-p)(-V)])$. Comparing this weighted average to the payoff for not investing (0), and solving for $r$, we see that $F$ will play $I$ when:

$$
r \geq \frac{1-p-p \gamma\left(1-\mu t^{\prime}\right)}{1-p-p \gamma\left(1-\mu t^{\prime}\right)+(1-q)(\gamma-c)-q}
$$

In words, if $F$ attributes the probability of war as greater than condition (7), he will invest.

We conclude that if $\omega \leq R \alpha(1-\mu)+V \gamma \mu t^{\prime}+C_{E}$ (condition 2), $\omega \geq R \alpha(1-\mu)+$ $V \gamma \mu t_{0}+C_{E}$ (condition 3), $\lambda \geq V \gamma \mu \tau$ (condition 4), $C_{T} \leq V \gamma \mu \tau$ (condition 6), and $r \geq$ $\frac{1-p-p \gamma\left(1-\mu t^{\prime}\right)}{1-p-p \gamma\left(1-\mu t^{\prime}\right)+(1-q)(\gamma-c)-q}$ (condition 7), a political risk equilibrium (as defined in proposition 1) exists for the game. 